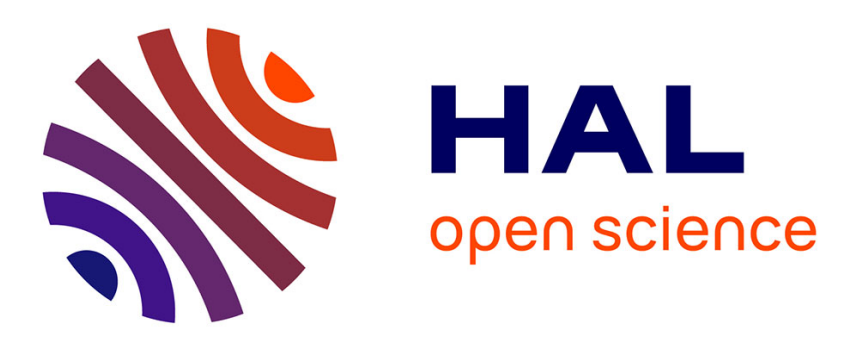

\title{
Hetero-hexalanthanide Complexes: A New Synthetic Strategy for Molecular Thermometric Probes
}

Haiyun Yao, Guillaume Calvez, Carole Daiguebonne, Kevin Bernot, Yan Suffren, Olivier Guillou

\section{- To cite this version:}

Haiyun Yao, Guillaume Calvez, Carole Daiguebonne, Kevin Bernot, Yan Suffren, et al.. Heterohexalanthanide Complexes: A New Synthetic Strategy for Molecular Thermometric Probes. Inorganic Chemistry, 2019, 58 (23), pp.16180-16193. 10.1021/acs.inorgchem.9b02668 . hal-02397303

HAL Id: hal-02397303

https://hal-univ-rennes1.archives-ouvertes.fr/hal-02397303

Submitted on 11 Dec 2019

HAL is a multi-disciplinary open access archive for the deposit and dissemination of scientific research documents, whether they are published or not. The documents may come from teaching and research institutions in France or abroad, or from public or private research centers.
L'archive ouverte pluridisciplinaire HAL, est destinée au dépôt et à la diffusion de documents scientifiques de niveau recherche, publiés ou non, émanant des établissements d'enseignement et de recherche français ou étrangers, des laboratoires publics ou privés. 


\section{Hetero-hexa-lanthanide complexes: A new synthetic strategy for molecular thermometric probes.}

Haiyun Yao, Guillaume Calvez*, Carole Daiguebonne*, Kevin Bernot, Yan Suffren and Olivier Guillou.

Univ Rennes, INSA Rennes, CNRS UMR 6226 "Institut des Sciences Chimiques de Rennes", F-35000 Rennes, France.

* To whom correspondence should be addressed 


\section{ABSTRACT}

Reactions in solvo-thermal or microwave-assisted conditions between a hexa-nuclear rare earth entity ([ $\left.\mathrm{Ln}_{6}\right]$ with $\mathrm{Ln}=$ Eu-Dy) and m-halogeno-benzoic acids lead to three series of isostructural complexes with respective chemical formulas $\left[\mathrm{Ln}_{6}\left(\mu_{3}-\mathrm{OH}\right)_{2}\left(\mathrm{H}_{2} \mathrm{O}\right)_{2}\left(\mathrm{NO}_{3}\right)_{2}(3-\mathrm{cb})_{14}\right] \cdot 4 \mathrm{CH}_{3} \mathrm{CN}, \quad\left[\mathrm{Ln}_{6}\left(\mu_{3}-\mathrm{OH}\right)_{2}\left(\mathrm{H}_{2} \mathrm{O}\right)_{2}\left(\mathrm{NO}_{3}\right)_{2}(3-\mathrm{bb})_{14}\right] \cdot 6 \mathrm{CH} \mathrm{CH}_{3} \mathrm{CN}$ and $\left[\mathrm{Ln}_{6}\left(\mu_{3}-\mathrm{OH}\right)_{2}\left(\mathrm{H}_{2} \mathrm{O}\right)_{2}\left(\mathrm{NO}_{3}\right)_{2}(3-\mathrm{ib})_{14}\right] \cdot 6 \mathrm{CH}_{3} \mathrm{CN}$ where 3-cb', 3-bb ${ }^{-}$and 3-ib- stand for 3-chloro-, 3-bromo- and 3-iodo-benzoate respectively. These three series of compounds are almost isostructural. Their luminescent properties, in the solid and solution states have been studied in details and compared. This study shows that hexa-nuclear complexes own strong inter-metallic energy transfers. This makes these complexes good candidates for thermometric probes in solid state or in solution state. 


\section{INTRODUCTION}

Because of the unique optical properties of lanthanide ions (sharp emission peaks, high color purity and long luminescence lifetimes), lanthanide-based coordination compounds (coordination polymers or complexes) have attracted great attention over the past decades. Indeed, they could find their application in various technological fields ${ }^{1-2}$ such as display ${ }^{3}$ and lighting, ${ }^{4-6}$ imaging, ${ }^{7-8}$ fight against counterfeiting ${ }^{9-11}$ or molecular thermometry. ${ }^{12-15}$ Some of these potential applications, such as ratiometric molecular thermometry or materials vintage, require hetero-poly-lanthanide compounds. ${ }^{15-20}$ Numerous lanthanide-based coordination polymers have been reported to date ${ }^{21-26}$ but examples of coordination polymers with hetero-poly-lanthanide complexes as metallic centers are still quite scarce ${ }^{27-31}$ and examples of hetero-lanthanide complexes, that can be isolated and used as molecular precursors, are even rarer. $^{32}$ Indeed, most often, hetero-poly-lanthanide complexes are obtained by one pot synthesis from simple rare earth salts or oxides. ${ }^{33-35}$ For more than a decade, our group is working on hexa-nuclear complexes with general chemical formula $\left[\mathrm{Ln}_{6}\left(\mu_{6}-\mathrm{O}\right)\left(\mu_{3}-\mathrm{OH}\right)_{8}\left(\mathrm{NO}_{3}\right)_{6}\left(\mathrm{H}_{2} \mathrm{O}\right)_{12}\right] \cdot 2 \mathrm{NO}_{3} \cdot 2 \mathrm{H}_{2} \mathrm{O}$, where $\mathrm{Ln}=\mathrm{Sm}-\mathrm{Lu}$ and $\mathrm{Y}$ (Figure 1 ), hereafter symbolized by $\left[\mathrm{Ln}_{6}\right]^{36-37}$

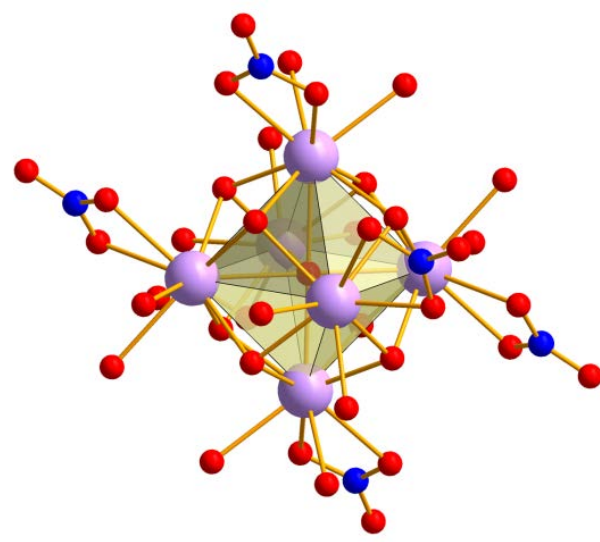

Figure 1. Projection view of the molecular motif of $\left[\mathrm{Dy}_{6}\right]$. Hydrogen atoms have been omitted for clarity. Redrawn from reference 36 (oxygen atoms are in red, nitrogen atoms in dark blue and Dy atoms in lavender blue). 
These complexes, first described by Zak and co-workers, ${ }^{38-41}$ can be synthesized in reasonable high yields by direct hydrolytic route. ${ }^{42}$ They can be described on the basis of a perfect octahedron with a lanthanide ion located on each vertex, a $\mu_{6}-\mathrm{O}^{2-}$ at the center and eight $\mu_{3}-\mathrm{OH}^{-}$groups capping the faces. They present weak stability in moist media and in most usual polar organic solvents. However, they are stable enough in some dry organic solvent to be used as molecular precursors. Actually, coordination polymers, nano-metric aggregates suspensions or complexes have already been obtained by using them as starting reactants. $^{43-45}$

Recently, it has been evidenced that strong inter-metallic energy transfer favors temperature-dependent luminescence in lanthanide-based coordination polymers. ${ }^{46}$ Therefore hexa-lanthanide-based complexes, in which inter-metallic distances are short, could constitute good candidates for ratiometric thermometric applications. In this paper, we describe the synthesis, the crystal structure and the luminescent properties of three families of quasi-isostructural complexes based on 3-chloro-, 3-bromo- and 3-iodo-benzoate ligands hereafter respectively symbolized by $3-\mathrm{cb}^{-}, 3-\mathrm{bb}^{-}$and $3-\mathrm{ib}{ }^{-}$. These series of complexes have respective general chemical formulae $\left[\mathrm{Ln}_{6}\left(\mu_{3}-\mathrm{OH}\right)_{2}\left(\mathrm{H}_{2} \mathrm{O}\right)_{2}\left(\mathrm{NO}_{3}\right)_{2}(3-\mathrm{cb})_{14}\right] \cdot 4 \mathrm{CH}_{3} \mathrm{CN}$ (hereafter symbolized by $\left.\left[\mathrm{Ln}_{6}(3-\mathrm{cb})_{14}\right]\right), \quad\left[\mathrm{Ln}_{6}\left(\mu_{3}-\mathrm{OH}\right)_{2}\left(\mathrm{H}_{2} \mathrm{O}\right)_{2}\left(\mathrm{NO}_{3}\right)_{2}(3-\mathrm{bb})_{14}\right] \cdot 6 \mathrm{CH}_{3} \mathrm{CN}$ (hereafter symbolized by $\left.\left[\mathrm{Ln}_{6}(3-\mathrm{bb})_{14}\right]\right)$ and $\left[\mathrm{Ln}_{6}\left(\mu_{3}-\mathrm{OH}\right)_{2}\left(\mathrm{H}_{2} \mathrm{O}\right)_{2}\left(\mathrm{NO}_{3}\right)_{2}(3-\mathrm{ib})_{14}\right] \cdot 6 \mathrm{CH}_{3} \mathrm{CN}$ (hereafter symbolized by $\left.\left[\operatorname{Ln}_{6}(3-i b)_{14}\right]\right)$ with $\mathrm{Ln}=$ Eu-Dy plus Y.

\section{EXPERIMENTAL SECTION}

\section{Synthesis.}

Lanthanide oxides (4N) were purchased from AMPERE Company and used without further purification. Starting hetero- and homo-hexa-lanthanide complexes with general chemical formula $\left[\mathrm{Ln}_{6}\left(\mu_{6}-\mathrm{O}\right)\left(\mu_{3}-\mathrm{OH}\right)_{8}\left(\mathrm{NO}_{3}\right)_{6}\left(\mathrm{H}_{2} \mathrm{O}\right)_{12}\right] \cdot 2 \mathrm{NO}_{3} \cdot 2 \mathrm{H}_{2} \mathrm{O}$ were prepared according 
to previously published procedures. ${ }^{42}$ m-halogeno-benzoic acids were purchased from TCI and used without further purification. Anhydrous acetonitrile was purchased from Acros Oganics and kept on molecular sieves.

$\left[\mathrm{Ln}_{6}(3-\mathrm{cb})_{14}\right]$ and $\left[\mathrm{Ln}_{6}(3-\mathrm{bb})_{14}\right]$ with Ln $=$ Eu-Dy plus Y

$5.10^{-3} \mathrm{mmol}$ of a hexa-nuclear rare earth entity $\left(\left[\operatorname{Ln}_{6}\right]\right), 6.10^{-2} \mathrm{mmol}$ of ligand, and $2 \mathrm{~mL}$ of dry acetonitrile were placed in a $24 \mathrm{~mL}$ Parr autoclave. Parr autoclave was heated between 60 and $130^{\circ} \mathrm{C}$, depending on the involved lanthanide ion, over a period of $100 \mathrm{~h}$. Then autoclave was cooled at a rate of $2^{\circ} \mathrm{C} \cdot \mathrm{h}^{-1}$. The resulting clear solution was then left for a few days at room-temperature in a closed vessel. After this time, single crystals appeared (Figure S1). They were filtered, washed with acetonitrile, and dried in ambient air. Experimental details for each lanthanide ion are listed in Table S1. From this table, one can notice that the smaller the radius of the lanthanide ion is, the higher the temperature of synthesis is. This may be related to the greater stability of the hexa-nuclear rare earth complexes that involve the smallest lanthanide ion. ${ }^{47}$

Iso-structurality of the different compounds has been assumed on the basis of their unit cell parameters. For hetero-lanthanide compounds, lanthanide ions contents were estimated by EDS measurements (Tables S2 and S3). Crystal structure of the compounds with general chemical formula $\left[\operatorname{Ln}_{6}(3-c b)_{14}\right]$ has been described previously (CCDC-1571385). ${ }^{45}$ Crystal structure of the compounds with general chemical formula [ $\left.\operatorname{Ln}_{6}(3-b b)_{14}\right]$ has been solved on the basis of the Dy-derivative.

By this method, each batch produces only a few crystals, $\sim 150 \mu \mathrm{g}$ per autoclave, the solvothermal synthetic process is quite long and despite great synthetic effort, we did not succeed in obtaining microcrystalline powders in high yields. This encouraged us to move toward microwave-assisted synthesis for the third series of complexes. The yield was not improved, but the synthetic time was considerably reduced. 


\section{$\left[\operatorname{Ln}_{6}(3-i b)_{14}\right]$ with Ln = Eu-Dy plus $\mathrm{Y}$}

The molecular precursor $\left(\left[\operatorname{Ln}_{6}\right]\right)\left(5.10^{-3} \mathrm{mmol}\right)$ and ligand $\left(5.10^{-2} \mathrm{mmol}\right)$ were mixed under stirring at room-temperature in a $10 \mathrm{~mL}$ tube that contained acetonitrile $(2 \mathrm{~mL})$. The suspension was microwave-heated at $100-160^{\circ} \mathrm{C}$ (depending on the involved lanthanide ion) at a power setting of $150 \mathrm{~W}$ and a maximum pressure of 2 bar. The solution was maintained at $100-160^{\circ} \mathrm{C}$ for $30 \mathrm{~min}$, then microwave heating was stopped and the mixture allowed to cool to room-temperature. The resulting clear solution was left for 3-7 days at room-temperature in a closed vessel. Single crystals appeared. They were filtered, washed with acetonitrile, and dried in ambient air. Isostructurality of the different compounds has been assumed on the basis of their unit cell parameters. For hetero-lanthanide compounds, lanthanide ions contents were estimated by SEM measurements (Tables S2 and S3). Crystal structure of compounds with general chemical formula $\left[\operatorname{Ln}_{6}(3-i b)_{14}\right]$ has been solved on the basis of the Dy-derivative.

\section{Single crystal X-ray diffraction.}

Single crystals were mounted on a D8 Venture Bruker diffractometer. Crystal data collections were performed with $\mathrm{MoK}_{\alpha}$ radiation $(\lambda=0.70713 \AA)$ at $150 \mathrm{~K}$. Crystal structures were solved by direct methods using the SIR97 program $^{48}$ and then refined with full matrix least-squares methods based on $\mathrm{F}^{2}$ (SHELX97) $^{49}$ with the aid of WINGX program. ${ }^{50}$ All non-hydrogen atoms were refined anisotropically using the SHELXL program. Hydrogen atoms bound to the organic ligand were located at ideal positions. Hydrogen atoms of water molecules were not localized. Absorption correction were performed using WinGX program facilities. ${ }^{50-51}$ Full details of the X-ray structure determination of the crystal structures of [Dy6 $\left.(3-b b)_{14}\right]$ and $\left[\mathrm{Dy}_{6}(3-\mathrm{ib})_{14}\right]$ have been deposited with the Cambridge Crystallographic Data Center under the depositary numbers CCDC-1871215 and CCDC-1875534 respectively. 


\section{Optical measurements.}

Solid state emission and excitation spectra have been measured on a Horiba Jobin-Yvon Fluorolog III fluorescence spectrometer equipped with a Xe lamp $450 \mathrm{~W}$, a UV-Vis photomultiplier (Hamamatsu R928, sensitivity $190-860 \mathrm{~nm}$ ). Quantum yield measurements were performed using a Jobin-Yvon integrating sphere $\left(\Phi=\left(E_{c}-E_{a}\right) /\left(L_{a}-L_{c}\right)\right.$ with $E_{c}$ being the integrated emission spectrum of the sample, $E_{a}$ the integrated "blank" emission spectrum, $L_{a}$ the "blank" absorption and $L_{c}$ the sample absorption at the excitation wavelength). The emission/excitation spectra and quantum yield recordings were realized on powder samples introduced in cylindrical quartz cells of $0.7 \mathrm{~cm}$ diameter and $2.4 \mathrm{~cm}$ height, which were placed directly inside the integrating sphere. The phosphorescence of the Gd-based microcrystalline powders placed in quartz capillary tubes have been measured at $77 \mathrm{~K}$ (Dewar + liquid nitrogen). For the measurements realized at variable temperature (77 K - $300 \mathrm{~K})$, the samples were introduced in an OptistatCF liquid nitrogen cooled cryostat from Oxford Instruments. For heptane solutions, measurements were done identically but only between $200 \mathrm{~K}$ and $300 \mathrm{~K}$ because of heptane freezing point. For the measurement between 263 and $343 \mathrm{~K}$ on the $\left[\mathrm{Tb}_{4} \mathrm{Eu}_{2}(3-\mathrm{ib})_{14}\right]$ compound in heptane solution (in an emission cuvette), an additional module (Peltier heating from Horiba Jobin-Yvon) has been used. Luminescence decays have also been measured at room-temperature using this apparatus with a Xenon flash lamp (phosphorescence mode). Lifetimes and quantum yields are averages of three independent determinations.

Appropriate filters were used to remove the residual excitation laser light, the Rayleigh scattered light and associated harmonics from spectra. All spectra were corrected for the instrumental response function. For quantum yield measurements below $300 \mathrm{~nm}$, the correction curves for our equipment were supported by comparison with luminescent 
references: a standard solution of $\mathrm{Cs}_{3}\left[\mathrm{~Tb}(\mathrm{dpa})_{3}\right]$ (terbium tris-dipicolinate) in buffer excited at $279 \mathrm{~nm}^{52}$ and $\mathrm{Na}\left[\mathrm{Eu}(\text { pic) })_{4}\right]$ (europium picolinate) in the solid state at $285 \mathrm{~nm}^{53}$

Solid and solution UV-visible absorption measurements have been performed with a Perkin Elmer Lambda 650 spectrometer equipped with a 60 mm integrated sphere.

\section{Colorimetric measurements.}

The CIE (Commission Internationale de l'Eclairage) (x, y) emission color coordinates $^{54-55}$ were calculated on the basis of the emission spectra: $\mathrm{X}=k \times \int_{380 \mathrm{~nm}}^{780 \mathrm{~nm}} I_{\lambda} \times x_{\lambda}$, $\mathrm{Y}=k \times \int_{380 \mathrm{~nm}}^{780 \mathrm{~nm}} I_{\lambda} \times y_{\lambda}$ and $\mathrm{Z}=k \times \int_{380 \mathrm{~nm}}^{780 \mathrm{~nm}} I_{\lambda} \times z_{\lambda}$ with $\mathrm{k}$ constant for the measurement system, $\mathrm{I}_{\lambda}$ sample spectrum intensity wavelength depending, $\mathrm{x}_{\lambda}, \mathrm{y}_{\lambda}, \mathrm{z}_{\lambda}$ trichromatic values $\mathrm{x}=\mathrm{X} /(\mathrm{X}+\mathrm{Y}+\mathrm{Z}), \mathrm{y}=\mathrm{Y} /(\mathrm{X}+\mathrm{Y}+\mathrm{Z})$ and $\mathrm{z}=\mathrm{Z} /(\mathrm{X}+\mathrm{Y}+\mathrm{Z})$. Mean $\mathrm{xyZ}$ values are given for each sample, which act as light sources (luminescent samples).

\section{Electronic microscopy and Energy Dispersive Spectroscopy (EDS).}

EDS measurements have been performed with a Hitachi TM-1000, Tabletop Microscope version 02.11 (Hitachi High-Technologies, Corporation Tokyo Japan) with EDS analysis system (SwiftED-TM, Oxford Instruments Link INCA). Samples were assembled on carbon discs, stuck on an aluminium stub fixed at $7 \mathrm{~mm}$ from EDX beam, with an angle of measurement of $22^{\circ}$. Reproducibility of the elemental analyses has been checked by repeating the measurements several times. Results, expressed in atom\%, are average values of different spots. These experiments support the homogeneity of the samples. 


\section{RESULTS AND DISCUSSION}

Reactions of a homo- or hetero-hexa-lanthanide molecular precursor of general chemical formula $\quad\left[\mathrm{Ln}_{6}\left(\mu_{6}-\mathrm{O}\right)\left(\mu_{3}-\mathrm{OH}\right)_{8}\left(\mathrm{NO}_{3}\right)_{6}\left(\mathrm{H}_{2} \mathrm{O}\right)_{12}\right] \cdot 2 \mathrm{NO}_{3} \cdot 2 \mathrm{H}_{2} \mathrm{O} \quad\left(\left[\mathrm{Ln}_{6}\right]\right) \quad$ with 3-chloro-benzoic acid, 3-bromo-benzoic acid or 3-iodo-benzoic acid (3-cbH, 3-bbH or 3-ibH) in acetonitrile, in solvothermal or microwave-assisted conditions, lead to three families of isostructural complexes depending on the ligand. Compounds that are obtained with 3-chloro-benzoic acid have general chemical formula $\left[\mathrm{Ln}_{6}\left(\mu_{3}-\mathrm{OH}\right)_{2}\left(\mathrm{H}_{2} \mathrm{O}\right)_{2}\left(\mathrm{NO}_{3}\right)_{2}(3-\mathrm{cb})_{14}\right] \cdot 4 \mathrm{CH}_{3} \mathrm{CN}$ (hereafter symbolized by $\left[\mathrm{Ln}_{6}(3-\mathrm{cb})_{14}\right]$ ) with Ln = Eu-Dy plus Y. They are all isostructural with $\left[\mathrm{Dy}_{6}(3-\mathrm{cb})_{14}\right]$ that has been previously described (Figures S2 and S3). ${ }^{45}$

Compounds that have been obtained with 3-bromo-benzoic acid or 3-iodo-benzoic acid have respective general chemical formula $\left[\mathrm{Ln}_{6}\left(\mu_{3}-\mathrm{OH}\right)_{2}\left(\mathrm{H}_{2} \mathrm{O}\right)_{2}\left(\mathrm{NO}_{3}\right)_{2}(3-\mathrm{bb})_{14}\right] \cdot 6 \mathrm{CH} 3 \mathrm{CN}$ (hereafter symbolized by $\left.\left[\mathrm{Ln}_{6}(3-b b)_{14}\right]\right)$ and $\left[\mathrm{Ln}_{6}\left(\mu_{3}-\mathrm{OH}\right)_{2}\left(\mathrm{H}_{2} \mathrm{O}\right)_{2}\left(\mathrm{NO}_{3}\right)_{2}(3-\mathrm{ib})_{14}\right] \cdot 6 \mathrm{CH}_{3} \mathrm{CN}$ (hereafter symbolized by $\left[\operatorname{Ln}_{6}(3-i b)_{14}\right]$ ) with $\operatorname{Ln}=$ Eu-Dy plus Y. They are all isostructural to [Dy6 $\left.(3-b b)_{14}\right]$ or $\left[\mathrm{Dy}_{6}(3-\mathrm{ib})_{14}\right]$, respectively. These three crystal structures are very close to each other: There are four crystallization acetonitrile molecules in [Dy $\left.\mathrm{D}_{6}(3-\mathrm{cb})_{14}\right]$ and six in [Dy6 $\left.(3-b b)_{14}\right]$ and $\left[\mathrm{Dy}_{6}(3-i b)_{14}\right]$ but molecular motifs are similar (Figure 2). Therefore, in the following, crystallographic figures will be drawn for [Dy6(3-bb) 14$]$, only. Crystal and final structure refinement data of the crystal structures are listed in Table 1. 

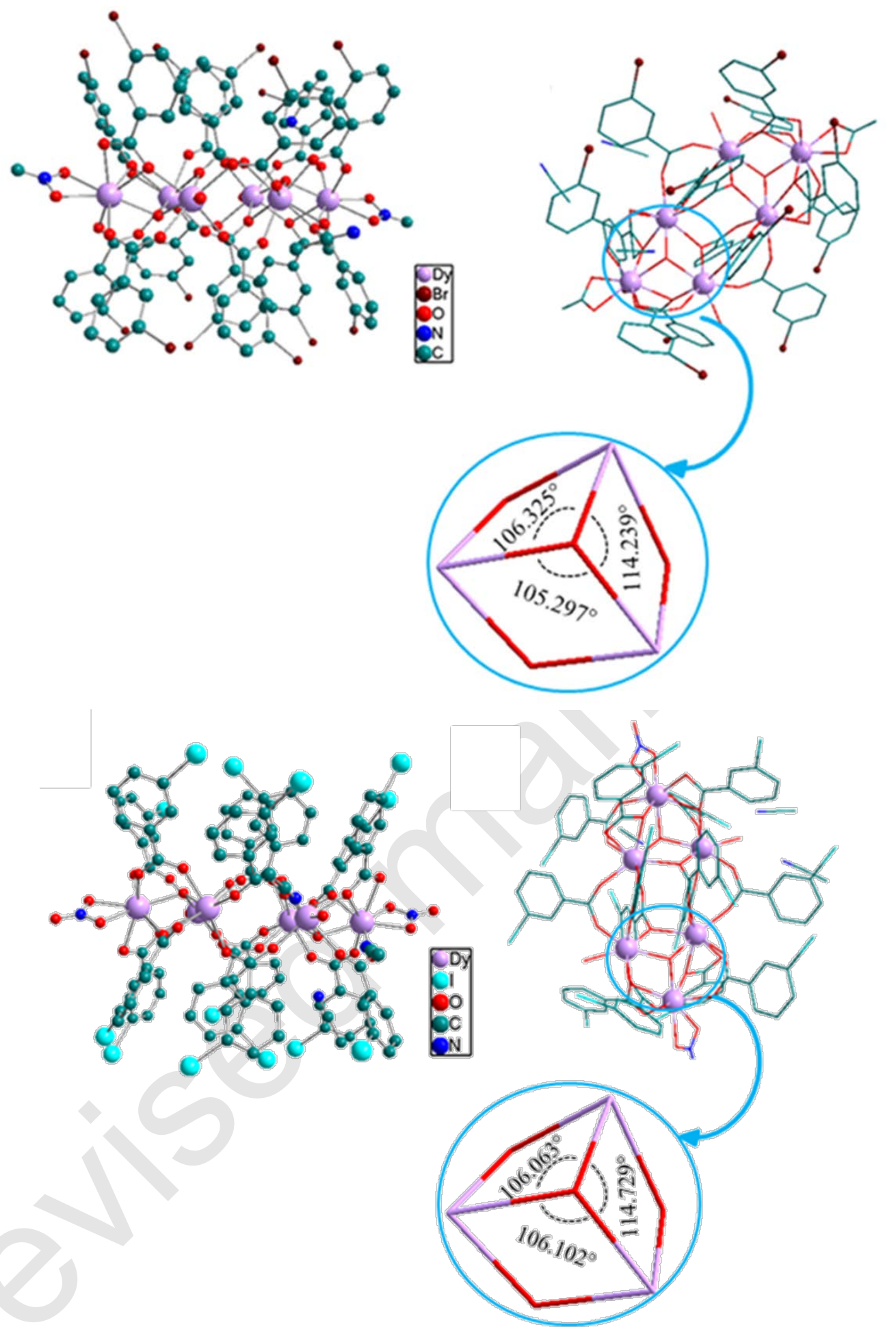

Figure 2. Projection views along the $a$-axis (left) and $b$-axis (right) of [Dy $\left.{ }_{6}(3-b b)_{14}\right]$ (top) and [Dy $\left.y_{6}(3-i b)_{14}\right]$ (bottom). In inset: triangular units with the Dy-O-Dy angles. 


\begin{tabular}{|c|c|c|c|}
\hline & {$\left[\mathrm{Dy}_{6}(3-\mathrm{cb})_{14}\right]$} & {$\left[\mathrm{Dy}_{6}(3-\mathrm{bb})_{14}\right]$} & {$\left[\mathrm{Dy}_{6}(3-\mathrm{ib})_{14}\right]$} \\
\hline Reference & 45 & This work & This work \\
\hline Molecular formula & $\mathrm{C}_{106} \mathrm{Cl}_{14} \mathrm{Dy}_{6} \mathrm{~N}_{6} \mathrm{O}_{38} \mathrm{H}_{56}$ & $\mathrm{C}_{110} \mathrm{Br}_{14} \mathrm{Dy}_{6} \mathrm{~N}_{8} \mathrm{O}_{38} \mathrm{H}_{74}$ & $\mathrm{C}_{110} \mathrm{I}_{14} \mathrm{Dy}_{6} \mathrm{~N}_{8} \mathrm{O}_{38} \mathrm{H}_{74}$ \\
\hline Formula weight $\left(\mathrm{g} \cdot \mathrm{mol}^{-1}\right)$ & 3492.96 & 4191.34 & 4867.38 \\
\hline System & Triclinic & Triclinic & Triclinic \\
\hline Space group $\left(\mathrm{n}^{\circ}\right)$ & $P-1(2)$ & $P-1(2)$ & $P-1(2)$ \\
\hline$a(\AA)$ & 13.9825(17) & $14.244(2)$ & $14.5429(18)$ \\
\hline$b(\AA)$ & 16.5065(19) & 16.799(2) & $17.109(2)$ \\
\hline$c(\AA)$ & $17.3472(18)$ & 17.155(3) & $17.434(2)$ \\
\hline$\alpha\left(^{\circ}\right)$ & $102.844(4)$ & 101.125(4) & $101.210(4)$ \\
\hline$\beta\left(^{\circ}\right)$ & $108.306(4)$ & 109.995(4) & $110.944(4)$ \\
\hline$\gamma\left({ }^{\circ}\right)$ & $111.950(4)$ & $112.935(4)$ & $112.455(4)$ \\
\hline $\mathrm{V}\left(\AA^{3}\right)$ & $3252.7(7)$ & $3290.5(8)$ & $3457.9(7)$ \\
\hline $\mathrm{Z}$ & 1 & 1 & 1 \\
\hline $\mathrm{D}_{\text {calc }}\left(\mathrm{g} \cdot \mathrm{cm}^{-3}\right)$ & 1.766 & 2.126 & 2.338 \\
\hline$\mu\left(\mathrm{mm}^{-1}\right)$ & 3.766 & 7.692 & 6.401 \\
\hline R (\%) & 4.71 & 9.83 & 3.55 \\
\hline $\mathrm{R}_{\mathrm{w}}$ & 14.32 & 31.78 & 8.25 \\
\hline GoF & 1.072 & 1.020 & 1.055 \\
\hline CCDC entry & 1571385 & 1871215 & 1875534 \\
\hline
\end{tabular}

These complexes can be described on the basis of two almost perfect equilateral triangles that form a quasi-planar hexagon with a lanthanide ion located at each vertex. Each triangle is capped by a $\mu_{3}-\mathrm{OH}^{-}$group which is a reminiscence of the starting hexa-lanthanide complex $\left[\mathrm{Dy}_{6}\right]$.

There are only three crystallographically independent lanthanide ions because an inversion center is located at the center of the hexagon. Dy1 is eight coordinated by seven oxygen atoms from six different ligands and one oxygen atom from the capping hydroxo group that form a slightly distorted dodecahedron. Dy2 is seven coordinated by five oxygen atoms from five different ligands, an oxygen atoms from the capping hydroxo group and an oxygen atom from a coordination water molecule that form a slightly distorted pentagonal bi-pyramid. Dy3 is eight coordinated by five oxygen atoms from four different ligands, one oxygen atom from the capping hydroxo group and two oxygen atoms from a bidentate nitrate ion that form a slightly distorted bi-augmented trigonal prism (Table 2). It can be noticed that this bidentate nitrate is reminiscent from the starting $\left[\mathrm{Ln}_{6}\right]$ complex. This has already been observed previously. ${ }^{56-57}$ 
It is also noticeable that there are only two coordination water molecules and two hydroxo groups per molecular motif in these crystal structures which induces that there are few O-H oscillators in the vicinity of the lanthanide ions.

Table 2. Geometrical data for $\mathrm{Dy}^{3+}$ coordination polyhedra in $\left[\mathrm{Dy}_{6}(3-\mathrm{cb})_{14}\right]$, [Dy6 $\left.(3-\mathrm{bb})_{14}\right]$ and $\left[\mathrm{Dy}_{6}(3-\mathrm{ib})_{14}\right]$.

\begin{tabular}{|c|c|c|c|}
\hline & {$\left[\mathrm{Dy}_{6}(3-\mathrm{cb})_{14}\right]$} & {$\left[\mathrm{Dy}_{6}(3-\mathrm{bb})_{14}\right]$} & {$\left[\mathrm{Dy}_{6}(3-\mathrm{ib})_{14}\right]$} \\
\hline Dy1 polyhedron & dodecahedron & dodecahedron & dodecahedron \\
\hline Agreement factor ${ }^{58-59}$ & 1.440 & 1.626 & 1.592 \\
\hline Dy1-O distances $(\AA)$ & $2.2785-2.4707$ & $2.2773-2.4687$ & $2.2849-2.4876$ \\
\hline Dy2 polyhedron & Pentagonal bi-pyramid & Pentagonal bi-pyramid & Pentagonal bi-pyramid \\
\hline Agreement factor ${ }^{58-59}$ & 0.872 & 0.794 & 0.706 \\
\hline Dy2-O distances $(\AA)$ & $2.1931-2.3551$ & $2.1771-2.3607$ & $2.1982-2.3677$ \\
\hline Dy3 polyhedron & $\begin{array}{l}\text { bi-augmented trigonal } \\
\text { prism }\end{array}$ & $\begin{array}{l}\text { bi-augmented trigonal } \\
\text { prism }\end{array}$ & $\begin{array}{l}\text { bi-augmented trigonal } \\
\text { prism }\end{array}$ \\
\hline Agreement factor ${ }^{58-59}$ & 2.631 & 2.591 & 2.512 \\
\hline Dy3-O distances $(\AA)$ & $2.2662-2.5003$ & $2.2666-2.4747$ & $2.2747-2.4850$ \\
\hline
\end{tabular}

Lanthanide ions that belong to the same molecular motif are close to each other (3.77-3.96 §̊) (Scheme 1 and Table 3).

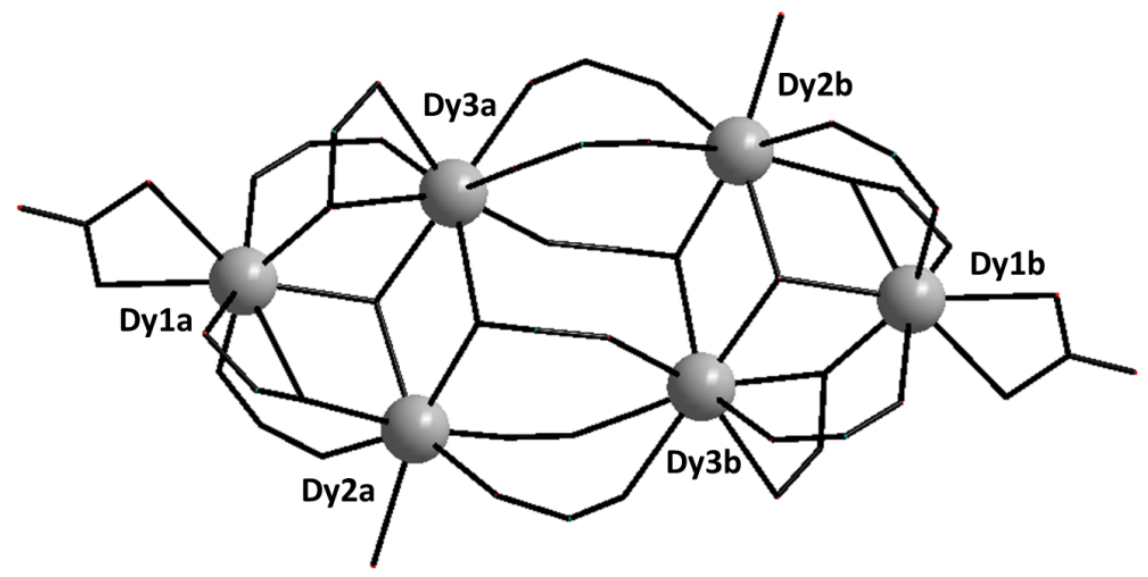

Scheme 1. Numbering scheme used in Table 3 for metal ions in [Dy $\left.(3-c b)_{14}\right]$, [Dy $\left.(3-b b)_{14}\right]$ and $\left[\mathrm{Dy}_{6}(3-\mathrm{ib})_{14}\right]$. 


\begin{tabular}{llcl}
\hline \multicolumn{5}{c}{ Table 3. Intra-molecular inter-metallic distances in the three complexes. } \\
\hline & {$\left[\mathrm{Dy}_{6}(3-\mathrm{cb})_{14}\right]$} & $\begin{array}{c}\text { Distances }(\AA) \\
{\left[\mathrm{Dy}_{6}(3-\mathrm{bb})_{14}\right]}\end{array}$ & {$\left[\mathrm{Dy}_{6}(3-\mathrm{ib})_{14}\right]$} \\
\hline Dy1a - Dy2a & $3.7727(4)$ & $3.7673(4)$ & $3.7669(5)$ \\
Dy1a - Dy3a & $3.7632(4)$ & $3.7557(5)$ & $3.7702(4)$ \\
Dy2a - Dy3a & $3.9607(4)$ & $3.9364(5)$ & $3.9561(4)$ \\
Dy1a - Dy1b & $11.0836(13)$ & $11.0242(19)$ & $11.0524(14)$ \\
Dy1a - Dy2b & $8.5086(8)$ & $8.4561(8)$ & $8.4804(11)$ \\
Dy1a - Dy3b & $7.7585(9)$ & $7.7425(9)$ & $7.7639(10)$ \\
Dy2a - Dy1b & $8.5086(8)$ & $8.4561(8)$ & $8.4804(11)$ \\
Dy2a - Dy2b & $7.0900(6)$ & $7.0488(9)$ & $7.0755(7)$ \\
Dy2a - Dy3b & $4.8035(6)$ & $4.8231(5)$ & $4.7743(6)$ \\
Dy3a - Dy1b & $7.7585(9)$ & $7.7425(9)$ & $7.7639(10)$ \\
Dy3a - Dy2b & $4.8035(6)$ & $4.8231(5)$ & $4.7743(6)$ \\
Dy3a - Dy3b & $5.2206(6)$ & $5.1584(6)$ & $5.0811(7)$ \\
\hline
\end{tabular}

Numbering scheme is the one depicted in scheme 1

There are fourteen m-halogeno-benzoate ligands bound to the hexagonal core according to three different coordination modes (Scheme 2).

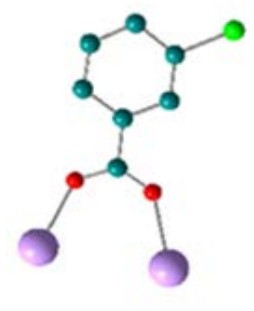

Mode I

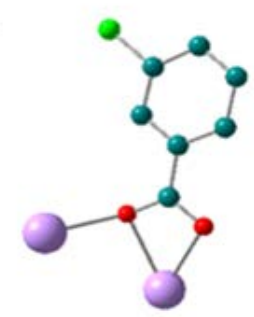

Mode II

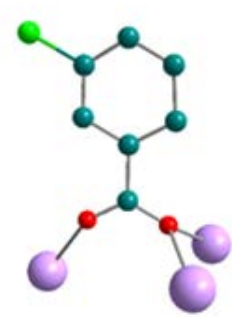

Mode III

Scheme 2. Schematic representations of the three coordination modes of the ligands that are encountered in the three crystal structures.

Halogen atoms are located at the periphery of the complex and point toward the inter-complexes space (Figure 3). They insure the stability of the crystal packing by halogen-bonds. ${ }^{60}$ Shortest distances between halogen atoms are quite long: $\mathrm{d}_{\mathrm{Cl}-\mathrm{Cl}}, \mathrm{d}_{\mathrm{Br}-\mathrm{Br}}$ and $\mathrm{d}_{\mathrm{I}-\mathrm{I}}$ are about $3.46 \AA, 3.55 \AA$ and $3.76 \AA$ respectively. Therefore, shortest inter-metallic distances between lanthanide ions that belong to adjacent complexes are of the order of $10 \AA$ $\left(10.9 \AA\right.$ in $\left[\mathrm{Dy}_{6}(3-\mathrm{cb})_{14}\right], 10.7 \AA$ in $\left[\mathrm{Dy}_{6}(3-\mathrm{bb})_{14}\right]$ and $10.9 \AA$ in $\left.\left[\mathrm{Dy}_{6}(3-\mathrm{ib})_{14}\right]\right)$ which is 
commonly admitted to be the distance above which inter-metallic energy transfers become less efficient. ${ }^{61-62}$

On the contrary inter-metallic energy transfers between lanthanide ions that belong to the same complex should be efficient. Therefore, in these compounds two different inter-metallic energy transfers must be distinguished and considered: outer energy transfer $\left(\mathrm{d}_{\mathrm{Ln}-\mathrm{Ln}} \approx 10.7-10.9 \AA\right)$ and inner energy transfer $\left(\mathrm{d}_{\mathrm{Ln}-\mathrm{Ln}} \approx 3.77-3.96 \AA\right) .{ }^{63-64}$
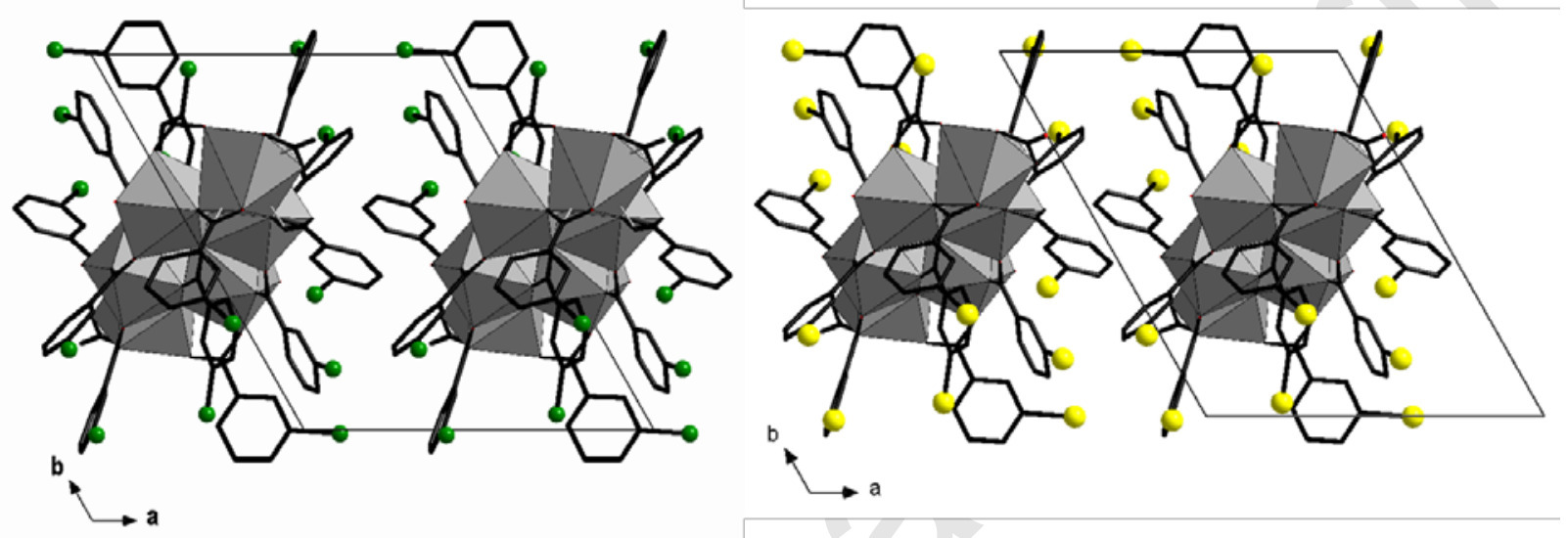

Figure 3. Projection views along the $c$-axis of the crystal packing of [Dy $\left.6(3-b b)_{14}\right]$ (left) and $\left[\mathrm{Dy}_{6}(3-\mathrm{ib})_{14}\right]$ (right). $\mathrm{Dy}^{3+}$ polyhedra have been drawn. Hydrogen atoms have been omitted for clarity.

This structural study evidences that structural differences between these three series of compounds are very small and therefore that they cannot be invoked to explain the observed different luminescent properties.

\section{Luminescence properties of homo-lanthanide complexes $\left[\operatorname{Ln}_{6}(3-c b)_{14}\right],\left[\operatorname{Ln}_{6}(3-b b)_{14}\right]$ and}

\section{$\left[\mathbf{L n}_{6}(3-i b)_{14}\right]$}

Solid state excitation and emission properties of the $\mathrm{Eu}^{3+}$ - and $\mathrm{Tb}^{3+}$-derivatives of these three series of complexes have been recorded at room-temperature (Figure 4). Luminescence properties of the $\mathrm{Dy}^{3+}$-derivatives are not reported because their emission is very weak and below the detection threshold of our experimental setup. Spectra reported in 
figure 4 evidence that the three ligands present an antenna effect ${ }^{65}$ for $\mathrm{Eu}^{3+}$ - as well as for $\mathrm{Tb}^{3+}$-derivatives.
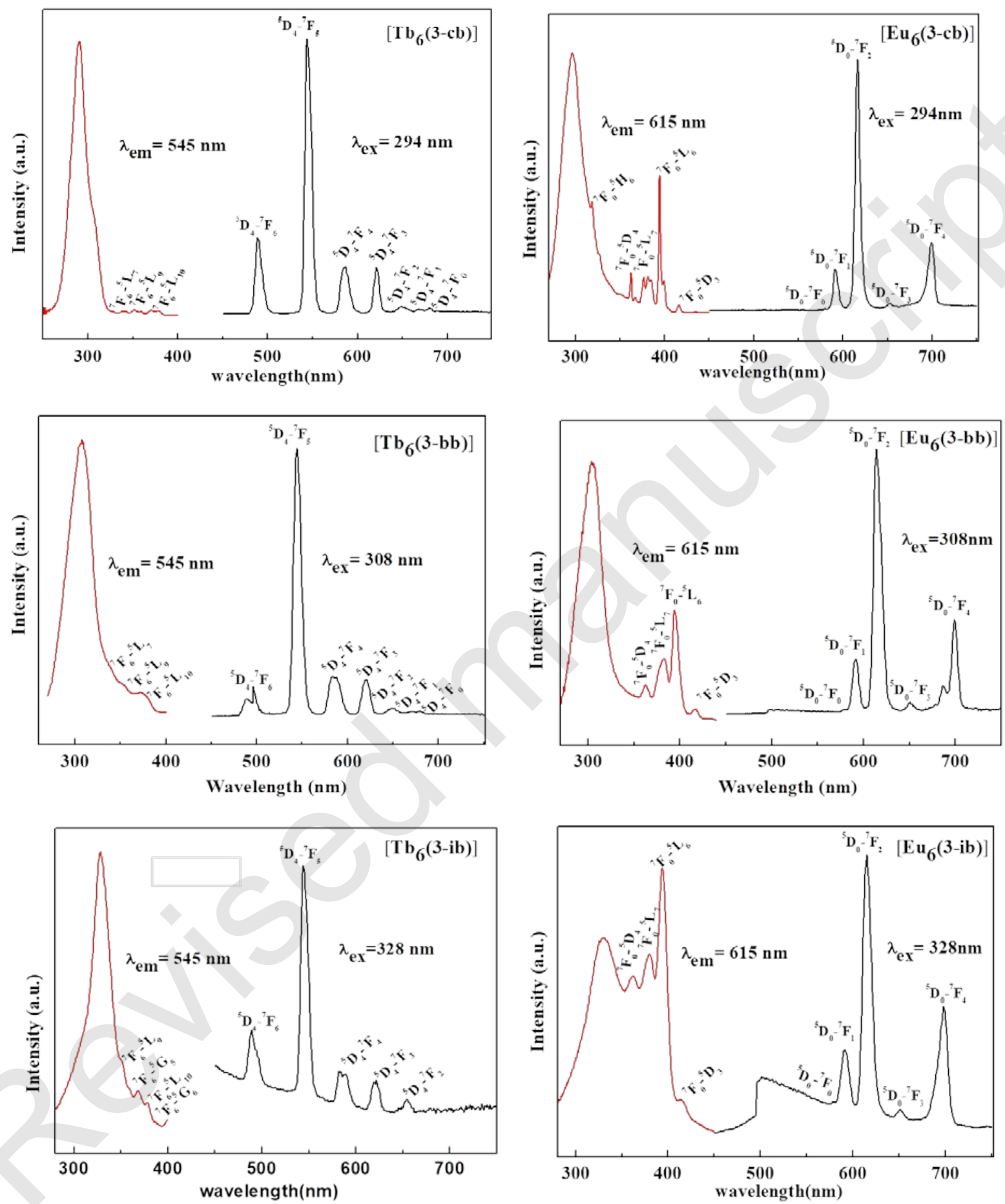

Figure 4. Solid state excitation and emission spectra of [ $\left.\operatorname{Ln}_{6}(3-c b)_{14}\right],\left[\operatorname{Ln}_{6}(3-b b)_{14}\right]$ and $\left[\mathrm{Ln}_{6}(3-\mathrm{ib})_{14}\right]$ with $\mathrm{Ln}=\mathrm{Eu}$ and $\mathrm{Tb}$ at room-temperature. 
On figure 4, excitation spectra of the $\mathrm{Tb}^{3+}$-derivatives present a broad band, with a maximum at $294 \mathrm{~nm}, 308 \mathrm{~nm}$ and $328 \mathrm{~nm}$ respectively, that can be attributed to ${ }^{1} \pi \rightarrow{ }^{1} \pi^{*} /{ }^{3} \pi^{*}$ transitions. $4 \mathrm{f} \rightarrow$ 4f transitions of $\mathrm{Tb}^{3+}$ ion $\left({ }^{7} \mathrm{~F}_{6} \rightarrow{ }^{5} \mathrm{~L}_{7}\right.$ at $341 \mathrm{~nm},{ }^{7} \mathrm{~F}_{6} \rightarrow{ }^{5} \mathrm{~L}_{9}$ at $352 \mathrm{~nm}$, ${ }^{7} \mathrm{~F}_{6} \rightarrow{ }^{5} \mathrm{~L}_{10}$ at $369 \mathrm{~nm}$ and ${ }^{7} \mathrm{~F}_{6} \rightarrow{ }^{5} \mathrm{G}_{6}$ at $380 \mathrm{~nm}$ ) are also visible but of weaker intensities. ${ }^{66-67}$ On the contrary $4 \mathrm{f} \rightarrow 4 \mathrm{f}$ transitions of the $\mathrm{Eu}^{3+}$ ion $\left({ }^{7} \mathrm{~F}_{0} \rightarrow{ }^{5} \mathrm{D}_{4}\right.$ at $365 \mathrm{~nm},{ }^{7} \mathrm{~F}_{0} \rightarrow{ }^{5} \mathrm{~L}_{7}$ at $381 \mathrm{~nm},{ }^{7} \mathrm{~F}_{0} \rightarrow{ }^{5} \mathrm{~L}_{6}$ at $394 \mathrm{~nm}$ and ${ }^{7} \mathrm{~F}_{0} \rightarrow{ }^{5} \mathrm{D}_{3}$ at $\left.414 \mathrm{~nm}\right)$ are much more intense. ${ }^{67-68}$ They are weaker than the excitation band of the ligand for $\left[\operatorname{Ln}_{6}(3-c b)_{14}\right]$ and $\left[\operatorname{Ln}_{6}(3-b b)_{14}\right]$ but for $\left[\mathrm{Eu}_{6}(3-\mathrm{ib})_{14}\right]$, the ${ }^{7} \mathrm{~F}_{0} \rightarrow{ }^{5} \mathrm{~L}_{6}$ (centered at $394 \mathrm{~nm}$ ) excitation peak is stronger than the excitation band of the 3-ib- ligand.

Room-temperature emission spectra of the $\left[\mathrm{Tb}_{6}(3-\mathrm{cb})_{14}\right]$ and $\left[\mathrm{Tb}_{6}(3-\mathrm{bb})_{14}\right]$ complexes $\left(\lambda_{\text {ex }}=294 \mathrm{~nm}\right.$ and $308 \mathrm{~nm}$, respectively) exhibit the characteristic emission bands of $\mathrm{Tb}^{3+}$ ions centered at $488 \mathrm{~nm}, 545 \mathrm{~nm}, 585 \mathrm{~nm}, 620 \mathrm{~nm} 650 \mathrm{~nm}, 668 \mathrm{~nm}$ and $680 \mathrm{~nm}$ which respectively correspond to the typical transitions: ${ }^{5} \mathrm{D}_{4} \rightarrow{ }^{7} \mathrm{~F}_{\mathrm{J}=6-0}$. Emission spectrum of $\left[\mathrm{Tb}_{6}(3-\mathrm{ib})_{14}\right]$ complex exhibits the first five peaks, but not the last two. Emission spectra are dominated by the ${ }^{5} \mathrm{D}_{4} \rightarrow{ }^{7} \mathrm{~F}_{5}$ transition (centered at $545 \mathrm{~nm}$ ) which results in green luminescence.

Emission spectra of the $\mathrm{Eu}^{3+}$-derivatives exhibit five emission peaks at $576 \mathrm{~nm}$, $588 \mathrm{~nm}, 615 \mathrm{~nm}, 650 \mathrm{~nm}$ and $699 \mathrm{~nm}$ which respectively correspond to the typical transitions ${ }^{5} \mathrm{D}_{0} \rightarrow{ }^{7} \mathrm{~F}_{0-4}$ under irradiation at $294 \mathrm{~nm}, 308 \mathrm{~nm}$ and $328 \mathrm{~nm}$, respectively. Emission spectra are dominated by the ${ }^{5} \mathrm{D}_{0} \rightarrow{ }^{7} \mathrm{~F}_{2}$ transition (centered at $615 \mathrm{~nm}$ ) which results in red luminescence.

Overall quantum yields $\left(\mathrm{Q}_{\mathrm{Ln}}^{\text {Ligand }}\right)$ and luminescence lifetimes $\left(\tau_{\mathrm{obs}}\right)$ have been measured for all these complexes at room-temperature. They are listed in Table 4. 
Table 4. Overall quantum yields and luminescence lifetimes for [ $\left.\operatorname{Ln}_{6}(3-\mathrm{Cb})_{14}\right],\left[\operatorname{Ln}_{6}(3-b b)_{14}\right]$ and $\left[\mathrm{Ln}_{6}(3-\mathrm{ib})_{14}\right](\mathrm{Ln}=\mathrm{Tb}, \mathrm{Eu})$ complexes under irradiation at $294 \mathrm{~nm}, 308 \mathrm{~nm}$ and $328 \mathrm{~nm}$, respectively.

\begin{tabular}{llllllll}
\hline & \multicolumn{2}{c}{$\left[\mathrm{Ln}_{6}(3-\mathrm{cb})_{14}\right]$} & \multicolumn{2}{c}{$\left[\operatorname{Ln}_{6}(3-\mathrm{bb})_{14}\right]$} & \multicolumn{2}{c}{$\left[\operatorname{Ln}_{6}(3-\mathrm{ib})_{14}\right]$} \\
& $\mathrm{Q}_{\mathrm{Ln}}^{\mathrm{Ligand}}(\%)$ & $\tau_{\text {obs }}(\mathrm{ms})$ & $\mathrm{Q}_{\mathrm{Ln}}^{\text {Ligand }}(\%)$ & $\tau_{\text {obs }}(\mathrm{ms})$ & $\mathrm{Q}_{\mathrm{Ln}}^{\mathrm{Ligand}}(\%)$ & $\tau_{\text {obs }}(\mathrm{ms})$ \\
\hline $\mathrm{Tb}$ & $88(9)$ & $1.16(2)$ & $65(7)$ & $1.27(2)$ & $3.5(5)$ & $0.88(7)$ \\
$\mathrm{Eu}$ & $25(3)$ & $0.45(4)$ & $21(4)$ & $0.37(4)$ & $2.0(5)$ & $0.23(4)$ \\
\hline
\end{tabular}

Sensitization efficiency ( $\eta_{\text {sens }}$ ) of ligands toward lanthanide ions is an important parameter defined by the following relationship: ${ }^{61}$

$Q_{\text {Ln }}^{\text {Ligand }}=\eta_{\text {sens }} Q_{\text {Ln }}^{\text {Ln }}=\eta_{\text {sens }} \frac{\tau_{\text {obs }}}{\tau_{\text {rad }}}$

Where $Q_{\mathrm{Ln}}^{\mathrm{Ln}}$ is the intrinsic quantum yield upon direct excitation of the lanthanide ions and $\tau_{\mathrm{rad}}$ is the radiative lifetime. $\tau_{\text {rad }}$ can be estimated by the following empirical relationship for $\mathrm{Eu}^{3+}$-containing compounds only: ${ }^{61}$

$\frac{1}{\tau_{\mathrm{rad}}}=\mathrm{A}_{\mathrm{MD}, 0} \cdot n \cdot\left(\frac{\mathrm{I}_{\mathrm{tot}}}{\mathrm{I}_{\mathrm{MD}}}\right)$

where $A_{M D, 0}$ is the spontaneous emission probability of the magnetic dipole ${ }^{5} D_{0} \rightarrow{ }^{7} F_{1}$ equal to $14.65 \mathrm{~s}^{-1}, n$ is the refractive index, $I_{\text {tot }}$ is the integrated emission of the ${ }^{5} \mathrm{D}_{0} \rightarrow{ }^{7} \mathrm{~F}_{\mathrm{J}=0-6}$ transitions and $\mathrm{I}_{\mathrm{MD}}$ is the integrated emission of the ${ }^{5} \mathrm{D}_{0} \rightarrow{ }^{7} \mathrm{~F}_{1}$ transition. Refractive index $n$ has been estimated to 1.50 on the basis of values for similar compounds. ${ }^{69}$

With these assumptions, calculated $\eta_{\text {sens }}$ values are $100(10) \%\left(\tau_{\text {rad }}=1.8(2) \mathrm{ms}\right)$, $74(7) \%\left(\tau_{\text {rad }}=1.3(2) \mathrm{ms}\right)$ and $23(2) \%\left(\tau_{\mathrm{rad}}=2.6(3) \mathrm{ms}\right)$ for $\left[\mathrm{Eu}_{6}(3-\mathrm{cb})_{14}\right],\left[\mathrm{Eu}_{6}(3-\mathrm{bb})_{14}\right]$ and $\left[\mathrm{Eu}_{6}(3-\mathrm{ib})_{14}\right]$, respectively. They are in agreement with excitation spectra of the three complexes (Figure 4) that clearly show a decreasing of the relative intensity of the excitation band attributed to the ligand for $\left[\mathrm{Eu}_{6}(3-\mathrm{ib})_{14}\right]$.

The small differences between the three crystal structures are not expected to explain such a big discrepancy between the overall quantum yields, luminescence lifetimes and sensitization efficiencies. This suggests that the electronic structure of the ligands is responsible. Therefore we have estimated the energy of the first excited singlet and triplet 
states of the three ligands. They were respectively experimentally determined on the basis of the wavelength of the first absorbance edge of the solid state absorption spectra recorded at room-temperature and on the basis of the lowest emission wavelength of the solid state emission spectra recorded at $77 \mathrm{~K}$ of the $\mathrm{Gd}^{3+}$-derivatives (Figures S4 and S5). ${ }^{61}$ Energies of ${ }^{1} \pi \rightarrow{ }^{1} \pi^{*}$ and ${ }^{1} \pi \rightarrow{ }^{3} \pi^{*}$ of the ligands in $\left[\mathrm{Gd}_{6}(3-\mathrm{cb})_{14}\right],\left[\mathrm{Gd}_{6}(3-\mathrm{bb})_{14}\right]$ and $\left[\mathrm{Gd}_{6}(3-\mathrm{ib})_{14}\right]$ are listed in Table 5.

Table 5. Estimated energies of the first excited singlet and triplet states of the ligands in $\left[\mathrm{Gd}_{6}(3-\mathrm{cb})_{14}\right],\left[\mathrm{Gd}_{6}(3-\mathrm{bb})_{14}\right]$ and $\left[\mathrm{Gd}_{6}(3-\mathrm{ib})_{14}\right]$.

\begin{tabular}{lcccccc}
\hline & \multicolumn{2}{c}{$\left[\mathrm{Gd}_{6}(3-\mathrm{cb})_{14}\right]$} & \multicolumn{2}{c}{$\left[\mathrm{Gd}_{6}(3-\mathrm{bb})_{14}\right]$} & \multicolumn{2}{c}{$\left[\mathrm{Gd}_{6}(3-\mathrm{ib})_{14}\right]$} \\
& $\lambda(\mathrm{nm})$ & $\mathrm{E}\left(\mathrm{cm}^{-1}\right)$ & $\lambda(\mathrm{nm})$ & $\mathrm{E}\left(\mathrm{cm}^{-1}\right)$ & $\lambda(\mathrm{nm})$ & $\mathrm{E}\left(\mathrm{cm}^{-1}\right)$ \\
\hline${ }^{1} \pi \rightarrow{ }^{1} \pi^{*}$ & 310 & 32250 & 320 & 31250 & 340 & 29400 \\
${ }^{1} \pi \rightarrow{ }^{3} \pi^{*}$ & 375 & 26650 & 385 & 26000 & 485 & 20600 \\
$\Delta \mathrm{E}\left({ }^{3} \pi^{*}{ }^{1} \pi^{*}\right)$ & $\mathrm{n} / \mathrm{a}$ & 5600 & $\mathrm{n} / \mathrm{a}$ & 5250 & $\mathrm{n} / \mathrm{a}$ & 8800 \\
\hline
\end{tabular}

Latva's empirical rules ${ }^{70}$ predict that energy of the first excited triplet state of the ligand in $\left[\mathrm{Eu}_{6}(3-\mathrm{ib})_{14}\right]$ allows good Ligand-to-Eu energy transfer without significant back-transfer and, on the contrary, predict that first excited triplet states of the ligands in [Eu $\left.\mathrm{Eu}_{6}(3-\mathrm{cb})_{14}\right]$ and $\left[\mathrm{Eu}_{6}(3-\mathrm{bb})_{14}\right]\left(26650 \mathrm{~cm}^{-1}\right.$ and $26000 \mathrm{~cm}^{-1}$ respectively) should not allow good efficiency of the Ligand-to-Eu energy transfer. However, for these two compounds, first excited triplet states can transfer energy to the ${ }^{5} \mathrm{~L}_{6}$ excited level of $\mathrm{Eu}^{3+}(\approx 394 \mathrm{~nm}$ or $\approx 25400 \mathrm{~cm}^{-1}$ ) that usually is efficient for feeding the emitting excited level ${ }^{5} \mathrm{D}_{0}{ }^{71-74}$ This hypothesis seems to be confirmed here by excitation spectra (Figure 4) that show that excitation at $394 \mathrm{~nm}$ provides quite intense $\mathrm{Eu}^{3+}$ luminescence (Scheme 3).This, combined with the weak number of $\mathrm{C}-\mathrm{H}$ oscillators in the neighboring of $\mathrm{Eu}^{3+}$ ions, can explain the quite high overall quantum yields measured for these two compounds although ligand excited triplet state energies are not optimized. 

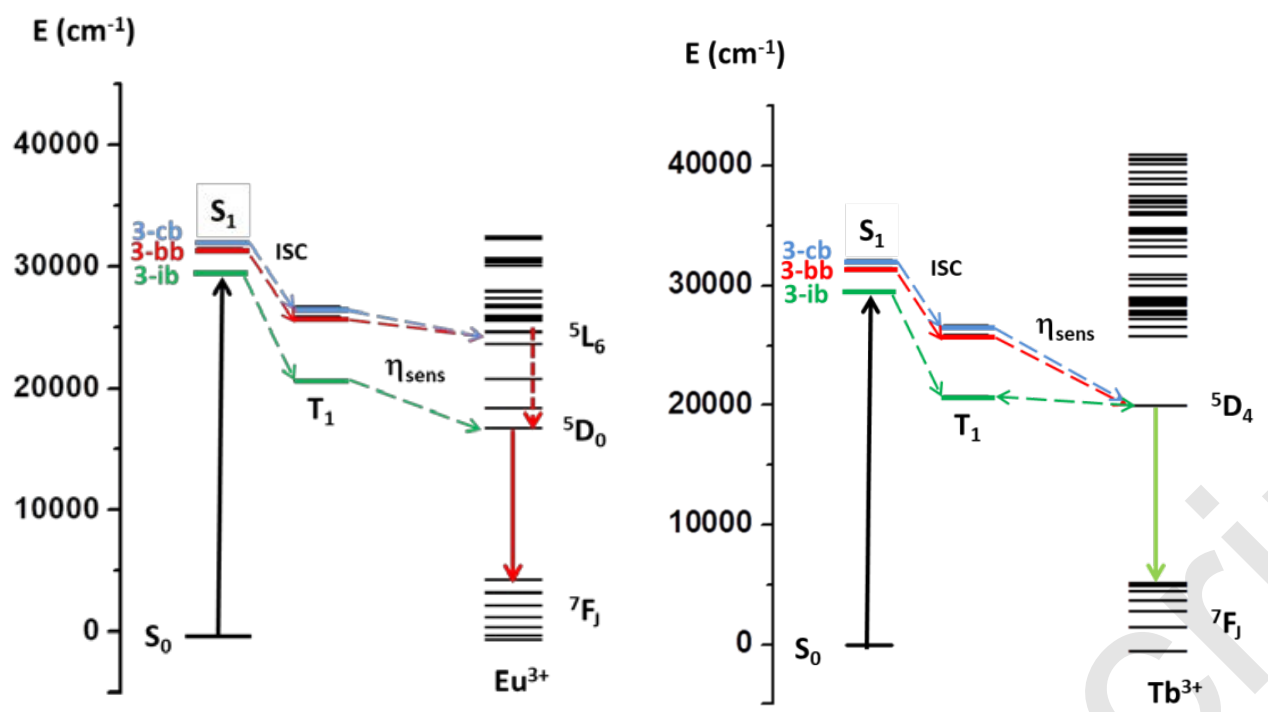

Scheme 3. Schematic representation of the energy levels of the ligands and of the $\mathrm{Eu}^{3+}$ ion $\left(\mathrm{E}\left({ }^{5} \mathrm{D}_{0}\right)=17350 \mathrm{~cm}^{-1}\right.$ and $\left.\mathrm{E}\left({ }^{5} \mathrm{~L}_{6}\right)=25400 \mathrm{~cm}^{-1}\right)$ (left) and $\mathrm{Tb}^{3+}$ ion $\left(\mathrm{E}\left({ }^{5} \mathrm{D}_{4}\right)=20500 \mathrm{~cm}^{-1}\right)$ (right). The colored arrows between $\mathrm{S}_{1}$ and $\mathrm{T}_{1}$ indicate the ISC transfers (Inter-System Crossing mechanisms) while those between $\mathrm{T}_{1}$ and ${ }^{5} \mathrm{~L}_{6} /{ }^{5} \mathrm{D}_{0-3}(\mathrm{Eu}(\mathrm{III}))$ or ${ }^{5} \mathrm{D}_{4}(\mathrm{~Tb}(\mathrm{III})$ ) indicate the energy transfers by sensitization $\left(\eta_{\text {sens }}\right)$. The vertical arrows up and down show the absorption from the ligand and emission from $\mathrm{Eu}(\mathrm{III})$ or $\mathrm{Tb}(\mathrm{III})$, respectively. The red vertical dotted arrow indicates the non-radiative de-excitation. The double green dotted arrow corresponds to potential back-transfers.

However, from Table 4, it can be noticed that, despite good agreement with Latva's rules, measured overall quantum yield and luminescence lifetime of [Eu6 $\left.(3-i b)_{14}\right]$ are drastically smaller than those measured for the two other compounds. Because crystal structures of the three compounds are almost identical, one can assume that emission under direct excitation of $\mathrm{Eu}^{3+}$ should be similar for the three compounds. Under this assumption, figure 4 clearly indicates that relative intensity of the broad excitation band attributed to the $\pi \rightarrow \pi^{*}$ transitions is weaker for $\left[\mathrm{Eu}_{6}(3-\mathrm{ib})_{14}\right]$. This decreasing can be related to a photo-induced electron transfer (PET) mechanism that can be observed when a donating group is present in the vicinity of an easily reducible lanthanide ion such as Eu(III). ${ }^{20,23,75-77}$ Indeed, halogen groups are known for being inductive-attractors (-I) and mesomeric-donors $(+\mathrm{M})$. Electro-attractor effect is usually dominant but decreases with electronegativity. ${ }^{78}$ Therefore, for iodine whose electronegativity is weak, mesomeric effect becomes 
predominant and iodine can be considered as a donor atom that can induce PET mechanism and reduce drastically Ligand-to-Metal energy transfer efficiency.

According to Reinhoudt's empirical rules, ${ }^{79}$ inter-system crossing process without significant back-transfer is efficient in all the three complexes $\left(\Delta \mathrm{E}\left({ }^{3} \pi^{*}{ }_{-}{ }^{1} \pi^{*}\right)>5000 \mathrm{~cm}^{-1}\right)$ which is in agreement with the observance of broad excitations bands attributed to ${ }^{1} \pi \rightarrow{ }^{1} \pi^{*} /{ }^{3} \pi^{*}$ transitions in the excitation spectra (Figure 4).

$\left[\mathrm{Tb}_{6}(3-\mathrm{cb})_{14}\right]$ and $\left[\mathrm{Tb}_{6}(3-\mathrm{bb})_{14}\right]$ exhibit high overall quantum yields and quite long luminescence lifetimes (Table 4). On the opposite, despite similar crystal structure, overall quantum yield and luminescence lifetime are much weaker for $\left[\mathrm{Tb}_{6}(3-\mathrm{ib})_{14}\right]\left(\mathrm{Q}_{\mathrm{Ln}}^{\mathrm{Ligand}} \approx 3.5 \%\right.$ and $\left.\tau_{\mathrm{obs}}=0.88(7) \mathrm{ms}\right)$. This is in agreement with Latva's empirical rules ${ }^{70}$ that predict efficient Ligand-to-Metal energy transfer for $\left[\mathrm{Tb}_{6}(3-\mathrm{cb})_{14}\right]$ and $\left[\mathrm{Tb}_{6}(3-\mathrm{bb})_{14}\right]\left(\Delta \mathrm{E}\left({ }^{1} \pi \rightarrow{ }^{3} \pi^{*-}{ }^{5} \mathrm{D}_{4}\right.\right.$ $\left.\left(20500 \mathrm{~cm}^{-1}\right)\right)$ are $6150 \mathrm{~cm}^{-1}$ and $5500 \mathrm{~cm}^{-1}$ respectively) and inefficient one, because of significant back-transfer $\left(\Delta \mathrm{E}\left({ }^{1} \pi \rightarrow{ }^{3} \pi^{*}{ }^{5} \mathrm{D}_{4}\right) \approx 100 \mathrm{~cm}^{-1}\right)$, for $\left[\mathrm{Tb}_{6}(3-\mathrm{ib})_{14}\right]$ (Scheme 3).

\section{Luminescence properties of hetero-lanthanide complexes [ $\left.\mathbf{Y}_{6 x} \mathbf{T b}_{6-6 x}(3-c b)_{14}\right]$,} $\left[Y_{6 x} T_{b_{6-6 x}}(3-b b)_{14}\right]$ and $\left[Y_{6 x} T b_{6-6 x}(3-i b)_{14}\right]$ with $0 \leq x \leq 0.9$. Dilution effect of the optically active lanthanide ions.

It has been proved that, in lanthanide based coordination polymers, because of lanthanide ions similar chemical behaviors, it is possible to dilute optically active lanthanide ions by non-acceptor ones which results in an enhancement of the overall luminescence by reducing intermetallic energy transfer. ${ }^{23,}{ }^{69}$ However, in the present case, it must be kept in mind that, even for sizeable diluting rate, some complexes will contain only $\mathrm{Tb}^{3+}$-ions because random distribution of the lanthanide ions leads to a statistical distribution of the composition of the hexa-lanthanide complexes used as reactants. ${ }^{43,}{ }^{47}$ Indeed it has been 
demonstrated that mean inter-metallic distance is not the only parameter that must be taken into account: existence of donor-acceptor dimeric units is important as well. ${ }^{80}$

In order to check if the dilution strategy may apply in these compounds we have prepared three series of isostructural complexes with various dilution rates: $\left[\mathrm{Y}_{6 x} \mathrm{~Tb}_{6-6 x}(3-\mathrm{cb})_{14}\right], \quad\left[\mathrm{Y}_{6 x} \mathrm{~Tb}_{6-6 x}(3-\mathrm{bb})_{14}\right]$ and $\left[\mathrm{Y}_{6 x} \mathrm{~Tb}_{6-6 x}(3-\mathrm{ib})_{14}\right]$ with $0 \leq x \leq 0.9$. Their luminescence properties have been studied (Figure S6 and Table 6).

Table 6. Overall quantum yields and luminescence lifetimes for $\left[\mathrm{Y}_{6 x} \mathrm{~Tb}_{6-6 x}(3-c b)_{14}\right]$, $\left[\mathrm{Y}_{6 x} \mathrm{~Tb}_{6-6 x}(3-\mathrm{bb})_{14}\right]$ and $\left[\mathrm{Y}_{6 x} \mathrm{~Tb}_{6-6 x}(3-\mathrm{ib})_{14}\right]$ vs $x$ under $294 \mathrm{~nm}, 308 \mathrm{~nm}$ or $328 \mathrm{~nm}$ excitation wavelength, respectively.

\begin{tabular}{ccccccc}
\hline & \multicolumn{2}{c}{$\left[\mathrm{Y}_{66} \mathrm{~Tb}_{6-6 x}(3-\mathrm{cb})_{14}\right]$} & \multicolumn{2}{c}{$\left[\mathrm{Y}_{6 x} \mathrm{~Tb}_{6-6 x}(3-\mathrm{bb})_{14}\right]$} & \multicolumn{2}{c}{$\left[\mathrm{Y}_{6 x} \mathrm{~Tb}_{6-6 x}(3-\mathrm{ib})_{14}\right]$} \\
$x$ & $\mathrm{Q}_{\mathrm{Tb}}^{\text {Ligand }}(\%)$ & $\tau_{\text {obs }}(\mathrm{ms})$ & $\mathrm{Q}_{\mathrm{Tb}}^{\text {Ligand }}(\%)$ & $\tau_{\text {obs }}(\mathrm{ms})$ & $\mathrm{Q}_{\mathrm{Tb}}^{\text {Ligand }}(\%)$ & $\tau_{\text {obs }}(\mathrm{ms})$ \\
\hline 0 & $88(8)$ & $1.2(1)$ & $65(6)$ & $1.3(1)$ & $3.5(4)$ & $0.9(1)$ \\
0.05 & $95(9)$ & $1.1(1)$ & $53(5)$ & $1.3(1)$ & $1.4(2)$ & $0.9(1)$ \\
0.1 & $83(8)$ & $1.1(1)$ & $55(5)$ & $1.3(1)$ & $4.8(5)$ & $0.8(1)$ \\
0.2 & $77(7)$ & $1.1(1)$ & $74(7)$ & $1.3(1)$ & $1.1(1)$ & $0.9(1)$ \\
0.5 & $63(6)$ & $1.1(1)$ & $68(7)$ & $1.4(1)$ & $0.5(1)$ & $0.9(1)$ \\
0.9 & $38(4)$ & $1.2(1)$ & $30(3)$ & $1.3(1)$ & $0.1(1)$ & $0.9(1)$ \\
\hline
\end{tabular}

These data show that there is an efficient dilution effect on the luminescence intensity for all the three series of compounds. Indeed in the three cases, the brightest compound is not the pure Tb-derivative $(x=0)$ and in the three cases brightness first increases (as inter-metallic energy transfers decrease) and then decreases when the content in $\mathrm{Tb}^{3+}$ ions becomes too weak. However, one can notice that maximum intensity is obtained for different doping concentration for the three series. This was unexpected and is still not fully understood.

\section{Luminescence properties of hetero-lanthanide complexes $\left[\operatorname{Tb}_{6 x} E u_{6-6 x}(3-c b)_{14}\right]$,} $\left[\mathrm{Tb}_{6 x} \mathrm{Eu}_{6-6 x}(3-\mathrm{bb})_{14}\right]$ and $\left[\mathrm{Tb}_{6 x} \mathrm{E} u_{6-6 x}(3-\mathrm{ib})_{14}\right]$ with $0 \leq x \leq 1$ : Studying intermetallic

\section{Tb-to-Eu energy transfers.}

In order to study Tb-to-Eu energy transfers and to estimate the tunable character of the luminescence of these complexes, we have prepared three series of isostructural compounds: 
$\left[\mathrm{Tb}_{6 x} \mathrm{Eu}_{6-6 x}(3-\mathrm{cb})_{14}\right],\left[\mathrm{Tb}_{6 x} \mathrm{Eu}_{6-6 x}(3-\mathrm{bb})_{14}\right]$ and $\left[\mathrm{Tb}_{6 x} \mathrm{Eu}_{6-6 x}(3-\mathrm{ib})_{14}\right]$ with $0 \leq x \leq 1$. Emission spectra and colorimetric coordinates versus $x$ are drawn in Figure 5.
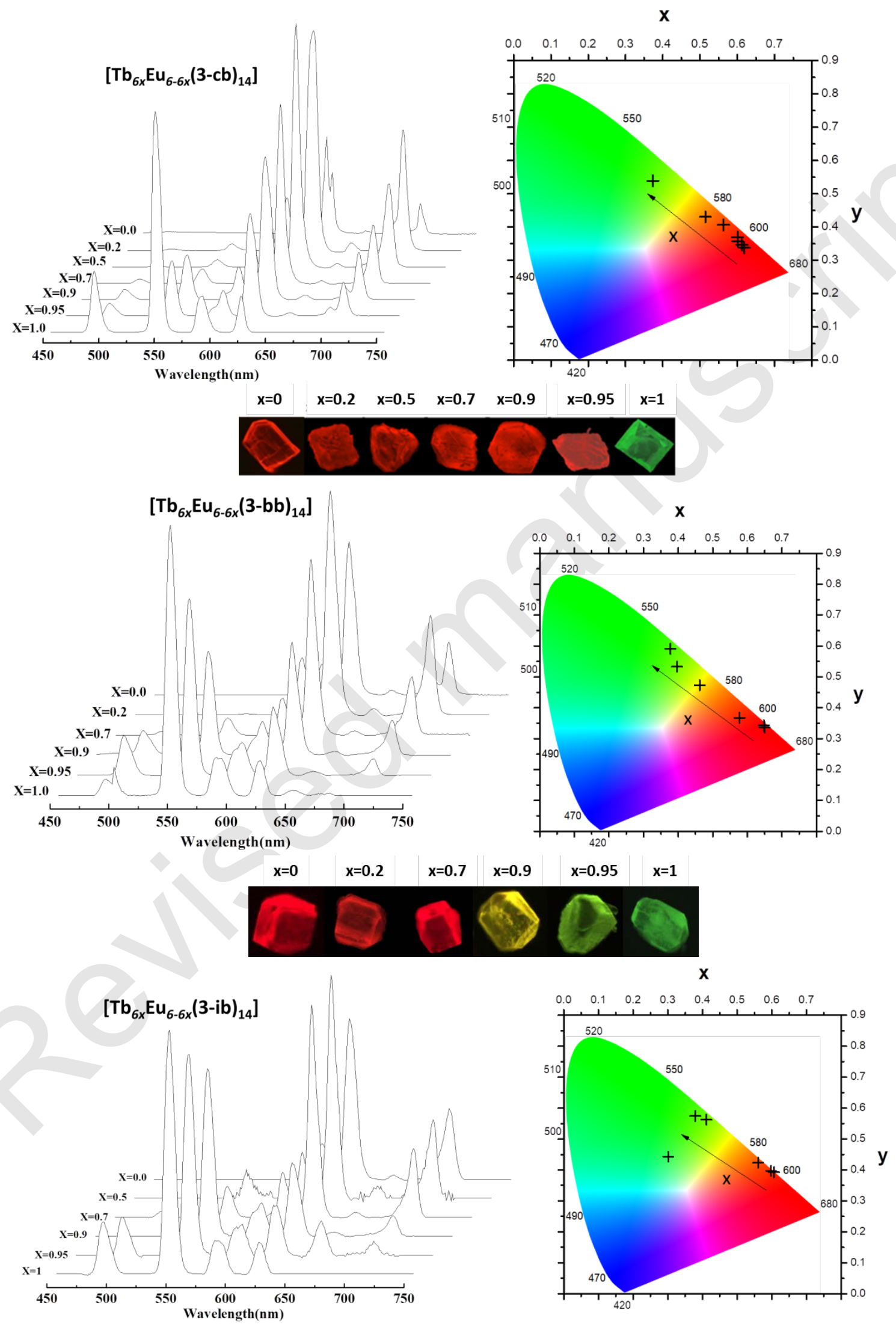


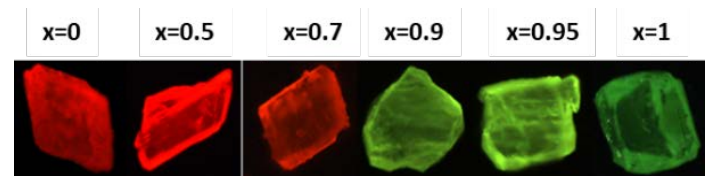

Figure 5. Pictures under UV irradiation $\left(\lambda_{\text {exc }}=312 \mathrm{~nm}\right)$, solid-state emission spectra and calculated colorimetric coordinates for $\left[\mathrm{Tb}_{6 x} \mathrm{Eu}_{6-6 x}(3-\mathrm{cb})_{14}\right], \quad\left[\mathrm{Tb}_{6 x} \mathrm{Eu}_{6-6 x}(3-\mathrm{bb})_{14}\right]$ and [ $\left.\mathrm{Tb}_{6 x} \mathrm{Eu}_{6-6 x}(3-\mathrm{ib})_{14}\right]$ with $0 \leq x \leq 1$. Excitation wavelengths are $294 \mathrm{~nm}, 308 \mathrm{~nm}$ and $328 \mathrm{~nm}$ for $\left[\mathrm{Tb}_{6 x} \mathrm{Eu}_{6-6 x}(3-\mathrm{cb})_{14}\right]$ (top), $\left[\mathrm{Tb}_{6 x} \mathrm{Eu}_{6-6 x}(3-\mathrm{bb})_{14}\right]$ (middle) and [ $\left.\mathrm{Tb}_{6 x} \mathrm{Eu}_{6-6 x}(3-\mathrm{ib})_{14}\right]$ (bottom), respectively.

Emission spectra of all these compounds present characteristic emission peaks of both $\mathrm{Eu}^{3+}$ and $\mathrm{Tb}^{3+}$ ions. For all the three series, relative intensities of these characteristic emission peaks strongly vary with $x$ which confirms that emission color modulation is possible. However, Figure 5 evidences that emission color variation highly depends on the series that is considered. In order to compare these different behaviors, we have calculated the integrated intensities ratio (hereafter symbolized by F) of ${ }^{5} \mathrm{D}_{4} \rightarrow{ }^{7} \mathrm{~F}_{5}\left(\mathrm{~Tb}^{3+}: 545 \mathrm{~nm}\right.$ ) and ${ }^{5} \mathrm{D}_{0} \rightarrow{ }^{7} \mathrm{~F}_{2}$ $\left(\mathrm{Eu}^{3+}: 613 \mathrm{~nm}\right.$ ) transitions (Figure S7). These two transitions have been chosen because they do not overlap with any other transition.

Figure S7 clearly shows that relative intensities of the two characteristic transitions are strongly dependent on the ligand. This was unexpected and suggests that ligands are involved in inter-metallic energy transfer mechanisms. Therefore intermetallic energy transfer efficiency $\left(\eta_{\mathrm{ET}}\right)$ must be different from a ligand to another (Scheme 4). $\eta_{\mathrm{ET}}$ has been calculated according to the following relationship: ${ }^{61}$

$\eta_{\mathrm{ET}}=1-\frac{\tau_{\mathrm{obs}}}{\tau_{0}}$

where $\tau_{\mathrm{obs}}$ and $\tau_{\mathrm{o}}$ are respectively luminescence lifetimes in presence and in absence of an acceptor lanthanide ion. In the present case, $\tau_{\mathrm{obs}}$ is the $\mathrm{Tb}^{3+}$ luminescence lifetime measured for a given $\mathrm{Tb} / \mathrm{Eu}$ hetero-lanthanide complex (Table 7) and $\tau_{0}$ is the $\mathrm{Tb}^{3+}$ luminescence lifetime of the corresponding $\mathrm{Tb} / \mathrm{Y}$ hetero-lanthanide complex in which $\mathrm{Eu}^{3+}$ ions are substituted by $\mathrm{Y}^{3+}$ ions (Table 6). $\eta_{\mathrm{ET}}$ values, $\mathrm{Eu}^{3+}$ and $\mathrm{Tb}^{3+}$ luminescence lifetimes and 
overall quantum yields $Q_{\mathrm{Tb}}^{\text {Ligand }}$ and $\mathrm{Q}_{\mathrm{Eu}}^{\mathrm{Ligand}}$ for the three series of Tb/Eu hetero-lanthanide complexes are gathered in Table 7.

Table 7. $\eta_{\mathrm{ET}}$ values, $\mathrm{Eu}^{3+}$ and $\mathrm{Tb}^{3+}$ luminescence lifetimes and overall quantum yields for $\left[\mathrm{Tb}_{6 x} \mathrm{Eu}_{6-6 x}(3-\mathrm{cb})_{14}\right],\left[\mathrm{Tb}_{6 x} \mathrm{Eu}_{6-6 x}(3-\mathrm{bb})_{14}\right]$ and $\left[\mathrm{Tb}_{6 x} \mathrm{Eu}_{6-6 x}(3-\mathrm{ib})_{14}\right]$ with $0 \leq x \leq 1$.

\begin{tabular}{|c|c|c|c|c|c|}
\hline \multicolumn{6}{|c|}{$\left[\mathrm{Tb}_{6 x} \mathrm{Eu}_{6-6 x}(3-\mathrm{cb})_{14}\right]$ with $0 \leq x \leq 1$} \\
\hline \multirow[t]{2}{*}{ 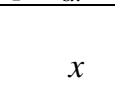 } & \multicolumn{2}{|c|}{$\mathrm{Tb}^{3+}$} & \multicolumn{2}{|c|}{$\mathrm{Eu}^{3+}$} & \multirow[b]{2}{*}{$\eta_{\mathrm{ET}}$} \\
\hline & $\mathrm{Q}_{\mathrm{Tb}}^{\text {Ligand }}(\%)$ & $\tau_{\mathrm{obs}}(\mathrm{ms})$ & $\mathrm{Q}_{\mathrm{Eu}}^{\text {Ligand }}(\%)$ & $\tau_{\text {obs }}(\mathrm{ms})$ & \\
\hline 0.2 & $0.2(2)$ & $0.16(3)$ & $27.0(2)$ & $0.52(3)$ & $85(2)$ \\
\hline 0.5 & $0.4(4)$ & $0.09(3)$ & $33.0(3)$ & $0.55(3)$ & $97(2)$ \\
\hline 0.7 & $2.0(2)$ & $0.17(3)$ & $35.5(3)$ & $0.54(3)$ & $84(2)$ \\
\hline 0.9 & $4.9(5)$ & $0.18(3)$ & $22.8(3)$ & $0.63(3)$ & $83(2)$ \\
\hline 0.95 & $7.7(5)$ & $0.29(3)$ & $20.6(3)$ & $0.66(3)$ & $73(2)$ \\
\hline & & \multirow[t]{2}{*}{ 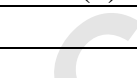 } & \\
\hline \multicolumn{3}{|c|}{$\frac{\left[\mathrm{Tb}_{6 x} \mathrm{Eu}_{6-6 x}(3-\mathrm{bb})_{14}\right] \text { with } 0 \leq x \leq 1}{\mathrm{~Tb}^{3+}}$} & $\mathrm{Eu}^{3+}$ & & \\
\hline$x$ & $\mathrm{Q}_{\mathrm{Tb}}^{\text {Ligand }}(\%)$ & $\tau_{\mathrm{obs}}(\mathrm{ms})$ & $\mathrm{Q}_{\mathrm{Eu}}^{\text {Ligand }}(\%)$ & $\tau_{\mathrm{obs}}$ (ms) & $\eta_{\mathrm{ET}}$ \\
\hline 0.2 & $1.0(2)$ & $0.29(3)$ & $27.94(2)$ & $0.74(3)$ & $77(2)$ \\
\hline 0.7 & $2.9(3)$ & $0.89(3)$ & $44.85(2)$ & $0.10(3)$ & $30(2)$ \\
\hline 0.9 & $27.2(3)$ & $1.18(3)$ & $30.60(2)$ & $0.01(3)$ & $6(2)$ \\
\hline 0.95 & $45.5(5)$ & $1.25(3)$ & $15.11(2)$ & $0.01(3)$ & $<1(2)$ \\
\hline \multicolumn{6}{|c|}{$\left[\mathrm{Tb}_{6 x} \mathrm{Eu}_{6-6 x}(3-\mathrm{ib})_{14}\right]$ with $0 \leq x \leq 1$} \\
\hline \multirow[b]{2}{*}{$x$} & \multicolumn{2}{|c|}{$\mathrm{Tb}^{3+}$} & \multicolumn{2}{|c|}{$\mathrm{Eu}^{3+}$} & \\
\hline & $\mathrm{Q}_{\mathrm{Tb}}^{\mathrm{Ligand}}(\%)$ & $\tau_{\text {obs }}(\mathrm{ms})$ & $\mathrm{Q}_{\mathrm{Eu}}^{\text {Ligand }}(\%)$ & $\tau_{\text {obs }}$ (ms) & $\eta_{\mathrm{ET}}$ \\
\hline 0.5 & $0.1(2)$ & $0.71(5)-$ & $1.2(2)$ & $0.49(3)$ & $19(2)$ \\
\hline 0.7 & $0.3(2)$ & $0.78(5)$ & $2.6(2)$ & $0.77(3)$ & $11(2)$ \\
\hline 0.9 & $2.0(3)$ & - & $0.4(2)$ & - & - \\
\hline 0.95 & $3.9(3)$ & - & $0.2(2)$ & - & - \\
\hline
\end{tabular}

From Table 7, one can notice that inter-metallic energy transfer is very efficient for all the chloro-benzoate complexes: even for $x=0.95$ (that is one $\mathrm{Eu}^{3+}$ ion for twenty $\mathrm{Tb}^{3+}$ ions) Tb-to-Eu inter-metallic energy transfer is still sizeable which evidences that, despite long inter-metallic distances, there is a sizeable inter-metallic energy transfer between lanthanide ions that belong to different complexes. This is in agreement with what has been previously published. ${ }^{45,81}$ These outer intermetallic energy transfers also exist in compounds based on bromo-benzoate and iodo-benzoate ligands but they are much weaker. This strongly suggests that halogen-bonds could participate to outer intermetallic energy transfers. 


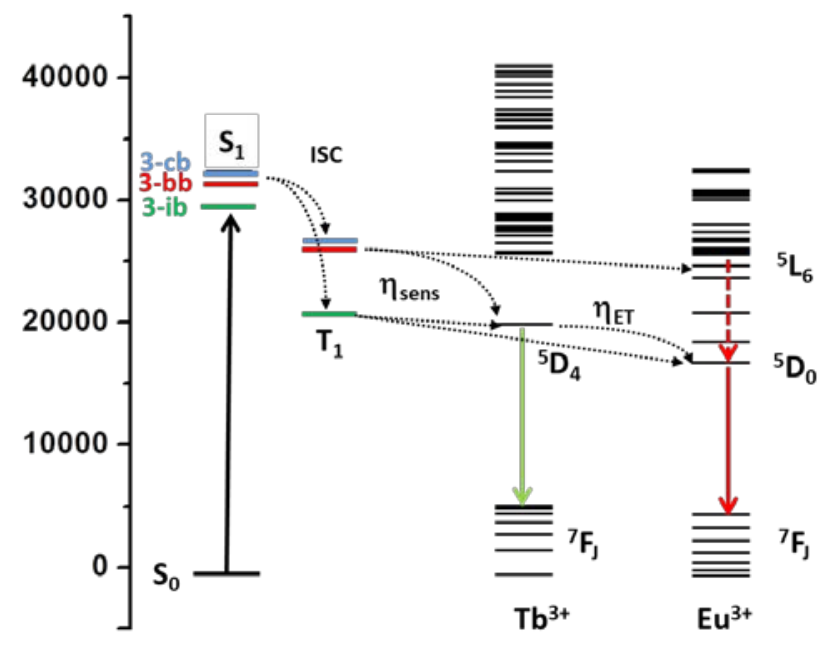

Scheme 4. Schematic representation of the energy transfer mechanisms that occur in $\left.\mathrm{Tb}_{6 x} \mathrm{Eu}_{6-6 x}(3-\mathrm{cb})_{14}\right],\left[\mathrm{Tb}_{6 x} \mathrm{Eu}_{6-6 x}(3-\mathrm{bb})_{14}\right]$ and $\left[\mathrm{Tb}_{6 x} \mathrm{Eu}_{6-6 x}(3-\mathrm{ib})_{14}\right]$ with $0 \leq x \leq 1$. The dark arrows between $S_{1}$ and $T_{1}$ indicate the ISC transfers (Inter-System Crossing mechanisms) while those between $\mathrm{T}_{1}$ and ${ }^{5} \mathrm{D}_{4}(\mathrm{~Tb}(\mathrm{III}))$ or ${ }^{5} \mathrm{~L}_{6} /{ }^{5} \mathrm{D}_{0-3}(\mathrm{Eu}(\mathrm{III}))$ indicate the energy transfers by sensitization ( $\left.\eta_{\text {sens }}\right)$ and those between ${ }^{5} \mathrm{D}_{4}(\mathrm{~Tb}(\mathrm{III}))$ and ${ }^{5} \mathrm{D}_{0}(\mathrm{Eu}(\mathrm{III}))$, the intermetallic energy transfers $\left(\eta_{\mathrm{ET}}\right)$. The vertical arrows up and down show the absorption from the ligand and red-green emission from Eu(III)-Tb(III), respectively. The red vertical dotted arrow indicates the non-radiative de-excitation.

Solid state temperature-dependent luminescent properties of hetero-hexa-lanthanide complexes $\left[\mathrm{Tb}_{4} \mathrm{Eu}_{2}(3-\mathrm{cb})_{14}\right],\left[\mathrm{Tb}_{4} \mathrm{Eu}_{2}(3-\mathrm{bb})_{14}\right]$ and $\left[\mathrm{Tb}_{4} \mathrm{Eu}_{2}(3-\mathrm{ib})_{14}\right]$ : Toward solid state ratiometric thermometer.

Temperature-dependent luminescence properties of molecular coordination compounds have been extensively investigated in recent years. ${ }^{17,}{ }^{22,}{ }^{82-84} \mathrm{Up}$ to now, no hexa-lanthanide complexes have been studied targeting their use as luminescent thermometers. Recently, it has been evidenced that temperature-dependence of the emission intensity of lanthanide based coordination polymers is closely related to inter-metallic energy transfers efficiency. ${ }^{46}$ Therefore, hetero-poly-lanthanide complexes, in which lanthanide ions are close to each other, could present interesting temperature-dependent luminescent properties. We have thus studied temperature-dependent luminescent properties of $\left[\mathrm{Tb}_{4} \mathrm{Eu}_{2}(3-\mathrm{cb})_{14}\right],\left[\mathrm{Tb}_{4} \mathrm{Eu}_{2}(3-\mathrm{bb})_{14}\right]$ and $\left[\mathrm{Tb}_{4} \mathrm{Eu}_{2}(3-\mathrm{ib})_{14}\right]$. This stoichiometry has been chosen because it corresponds to $x \approx 0.7$ (in the formalism used in the previous section) that is a stoichiometry that provides for all the three compounds a sizeable $\eta_{\mathrm{ET}}$ value (Table 7). 
Solid-state emission spectra as well as calculated colorimetric coordinates versus temperature are drawn in Figure 6 for the three complexes. This figure clearly indicates that these complexes exhibit strongly temperature-dependent luminescence.
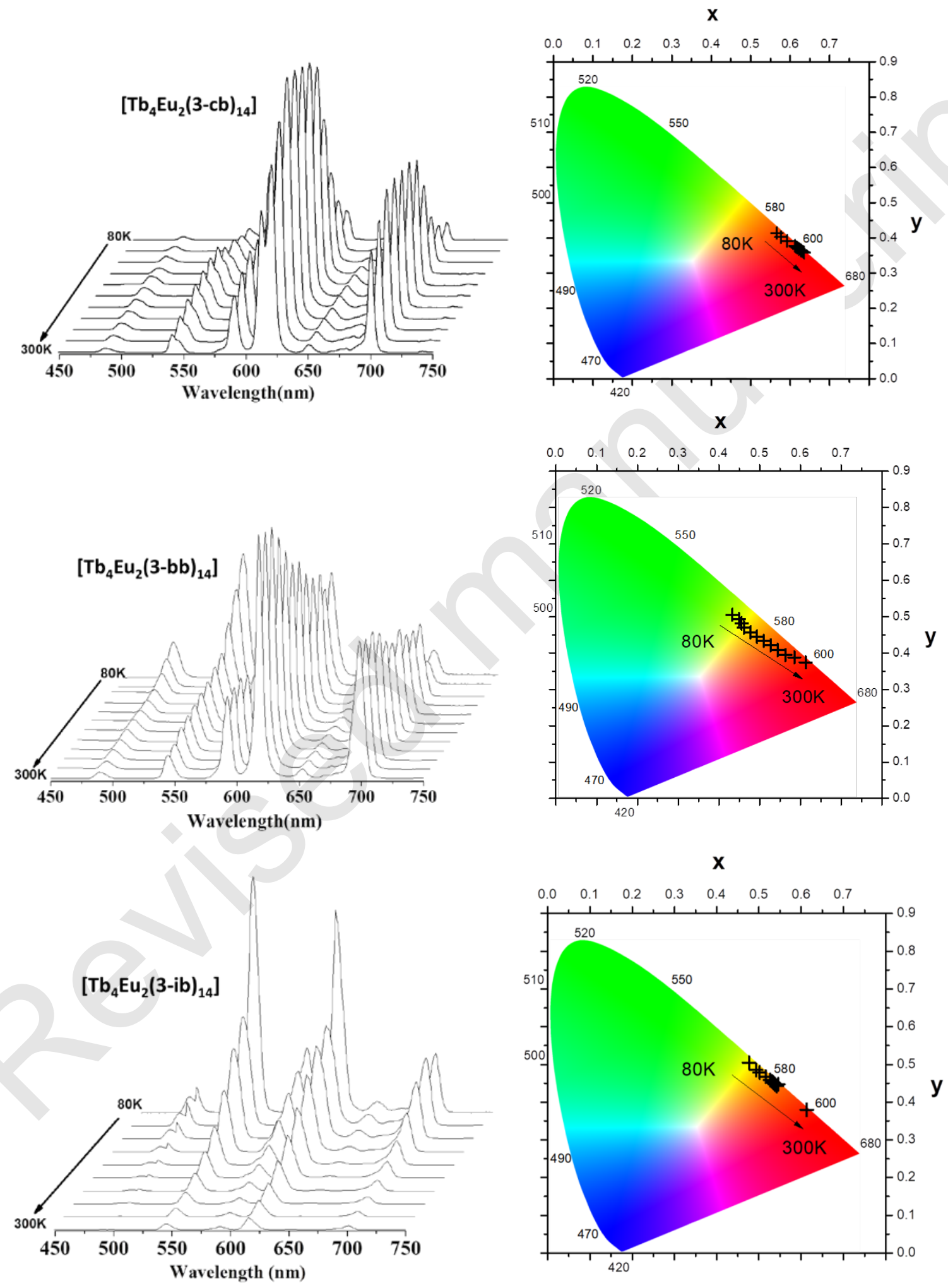
Figure 6. Solid state emission spectra and colorimetric coordinates of $\left[\mathrm{Tb}_{4} \mathrm{Eu}_{2}(3-\mathrm{cb})_{14}\right]$ (Top. $\left.\lambda_{\text {exc }}=298 \mathrm{~nm}\right), \quad\left[\mathrm{Tb}_{4} \mathrm{Eu}_{2}(3-\mathrm{bb})_{14}\right] \quad$ (Middle. $\left.\quad \lambda_{\text {exc }}=308 \mathrm{~nm}\right) \quad$ and $\quad\left[\mathrm{Tb}_{4} \mathrm{Eu}_{2}(3-\mathrm{ib})_{14}\right]$ (Bottom. $\lambda_{\mathrm{exc}}=328 \mathrm{~nm}$ ) versus temperature $(80-300 \mathrm{~K})$.

In order to compare these systems with other already published ones, one must calculate their relative sensitivities $\left(\mathrm{S}_{\mathrm{r}}\right)$ which is defined as follows:

$\mathrm{S}_{\mathrm{r}}=\frac{\frac{\partial \mathrm{P}}{\partial \mathrm{T}}}{\mathrm{P}}$

where $\mathrm{P}$ is the parameter that has been chosen for following the temperature-dependence of the luminescence. ${ }^{85-86}$ In the present case, we have chosen to define $\mathrm{P}$ as the ratio of the integrated intensities of the ${ }^{5} \mathrm{D}_{4} \rightarrow{ }^{7} \mathrm{~F}_{5}$ transition for $\mathrm{Tb}^{3+}\left(\mathrm{I}_{\mathrm{Tb}}\right)$ and the ${ }^{5} \mathrm{D}_{0} \rightarrow{ }^{7} \mathrm{~F}_{2}$ transition for $\mathrm{Eu}^{3+}\left(\mathrm{I}_{\mathrm{Eu}}\right)$ :

$\mathrm{P}=\frac{\mathrm{I}_{\mathrm{Tb}}}{\mathrm{I}_{\mathrm{Eu}}}$

Combining relationships (4) and (5) leads to:

$\mathrm{S}_{\mathrm{r}}=\frac{\frac{\partial\left(\frac{\mathrm{I}_{\mathrm{Tb}}}{\mathrm{I}_{\mathrm{Eu}}}\right)}{\partial \mathrm{T}}}{\frac{\mathrm{I}_{\mathrm{Tb}}}{\mathrm{I}_{\mathrm{Eu}}}}$

Maximum sensitivity $\mathrm{S}_{\mathrm{r}}$ have been calculated (Figures S8 to S10). Results are gathered in Table 8.

\begin{tabular}{cccc}
\hline \multicolumn{4}{c}{ Table 8. Relative sensitivities for $\left[\mathrm{Tb}_{4} \mathrm{Eu}_{2}(3-\mathrm{cb})_{14}\right],\left[\mathrm{Tb}_{4} \mathrm{Eu}_{2}(3-\mathrm{bb})_{14}\right]$ and $\left[\mathrm{Tb}_{4} \mathrm{Eu}_{2}(3-\mathrm{ib})_{14}\right]$} \\
\cline { 2 - 4 } & {$\left[\mathrm{Tb}_{4} \mathrm{Eu}_{2}(3-\mathrm{cb})_{14}\right]$} & $\left.\mathrm{Tb}_{4} \mathrm{Eu}_{2}(3-\mathrm{bb})_{14}\right]$ & {$\left[\mathrm{Tb}_{4} \mathrm{Eu}_{2}(3-\mathrm{ib})_{14}\right]$} \\
\cline { 2 - 4 } Sensitivity temperature range (K) & $80-300$ & $80-300$ & $80-300$ \\
Maximum sensitivity $\mathrm{S}_{\mathrm{r}}\left(\% . \mathrm{K}^{-1}\right)$ & 0.32 at $300 \mathrm{~K}$ & 3.35 at $120 \mathrm{~K}$ & 0.92 at $80 \mathrm{~K}$ \\
\hline
\end{tabular}

These values compare well with values that have already been reported before for coordination compounds ${ }^{82,84,87}$ and confirm that hetero-poly-lanthanide complexes are good candidates for thermometric probes. Moreover, the maximum sensitivity of the $\left[\mathrm{Tb}_{4} \mathrm{Eu}_{2}(3-\mathrm{cb})_{14}\right]$ complex is located around room-temperature which can constitutes an asset for some technological and biological applications. 


\section{Liquid state temperature-dependent luminescent properties of hetero-hexa-lanthanide complex $\left[\mathrm{Tb}_{4} \mathrm{Eu}_{2}(3-\mathrm{ib})_{14}\right]$ : Toward liquid state ratiometric thermometer.}

Most often, ratiometric molecular probes are coordination polymers. On the contrary, compounds that are described in this paper are complexes. This constitutes an asset as far as solution state thermometric probes are targeted. Indeed, it has been previously demonstrated that compounds that are iso-structural to $\left[\mathrm{Dy}_{6}(3-\mathrm{cb})_{14}\right]$ can be dissolved in non-polar solvents such as hexane or pentane without being destroyed. ${ }^{45}$ Therefore, we have prepared solutions of $\left[\mathrm{Eu}_{3} \mathrm{~Tb}_{3}(3-\mathrm{cb})_{14}\right]$ in hexane, heptane and pentane $\left(\mathrm{C}_{0}=2.10^{-3}\right.$ mol. $\left.\mathrm{L}^{-1}\right)$. As shown in Figures 7 and S11, their colorimetric coordinates are almost identical to the one of $\left[\mathrm{Eu}_{3} \mathrm{~Tb}_{3}(3-\mathrm{cb})_{14}\right]$ in the solid state and do not vary upon dilution from $C_{0}$ to $C_{0} / 5$ ). This confirms that hexa-lanthanide complexes are not destroyed upon dissolution because inter-metallic energy transfers are still present.

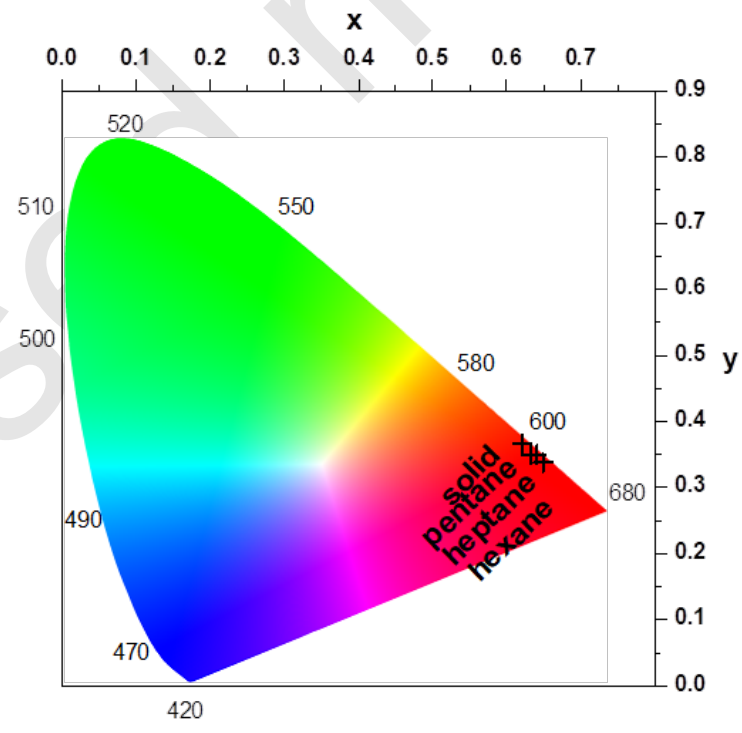

Figure 7. Colorimetric coordinates of $\left[\mathrm{Eu}_{3} \mathrm{~Tb}_{3}(3-\mathrm{cb})_{14}\right]$, in the solid state and dissolved in pentane, hexane and heptane $\left(\mathrm{C}_{0}=2 \cdot 10^{-3} \mathrm{~mol}^{-\mathrm{L}^{-1}}\right)$.

On the basis of these results, we have prepared heptane (b.p. $=98^{\circ} \mathrm{C}$; m.p. $=-90^{\circ} \mathrm{C}$ ) solution of $\left[\mathrm{Tb}_{4} \mathrm{Eu}_{2}(3-\mathrm{ib})_{14}\right] \quad\left(\mathrm{C}_{0}=2.10^{-3} \mathrm{mol.} \mathrm{L}^{-1}\right)$ and recorded its luminescence vs 
temperature (Figure S12) between $200 \mathrm{~K}$ and $343 \mathrm{~K}$ in solution. This complex has been chosen because of its faster synthesis. Its maximum sensitivity, $1.4 \% . \mathrm{K}^{-1}$ at $343 \mathrm{~K}$, has been calculated (Figure S13).

These results evidence that it should be possible to prepare liquid state thermometric probes, usable in a wide temperature range around room-temperature and with sizeable sensitivities. However it may be noticed that, unexpectedly, for this compound, sensitivities, in the solution and solid states, present opposite temperature dependence. At this time, we have no explanation but it could be related to the fact that outer energy transfers are much weaker in the solution state than in the solid state.

\section{CONCLUSION AND OUTLOOKS.}

In this paper we have described the luminescence properties of three series of almost isostructural hexa-lanthanide complexes. These families of complexes that are based on 3-chloro-, 3-bromo- and 3-iodo-benzoate as ligand exhibit very different luminescence properties which evidence that ligands are involved in inter-metallic energy transfer mechanisms.

Moreover results described in this paper demonstrate that hetero-poly-lanthanide complexes constitute interesting candidates for solid state and solution state thermometric probes around room-temperature.

\section{ACKNOWLEDGEMENTS}

The China Scholarship Council Ph.D. Program, a cooperation program with the French UT \& INSA, is acknowledged for financial support. Pr. Anne Sophie Chauvin (EPFL) is warmly acknowledged for providing luminescent standards for calibrating our integrating 
sphere at low excitation wavelengths. M. Gwendal Mazière is acknowledged for his help during solution-state luminescence measurements.

\section{SUPPORTING INFORMATION}

Pictures of $\left[\operatorname{Ln}_{6}(3-c b)_{14}\right](\mathrm{Ln}=\mathrm{Eu}$ and $\mathrm{Tb})$ under UV irradiation $\left(\lambda_{\text {exc }}=312 \mathrm{~nm}\right)$; Synthetic details of the syntheses of $\left[\operatorname{Ln}_{6}(3-c b)_{14}\right]$ and $\left[\operatorname{Ln}_{6}(3-b b)_{14}\right](\mathrm{Ln}=\mathrm{Eu}-\mathrm{Tb})$; Relative contents of $\mathrm{Ln}$ and $\mathrm{Ln}$ ' for $\left[\mathrm{Y}_{6 \mathrm{x}} \mathrm{Tb}_{6-6 \mathrm{x}}(3-\mathrm{cb} / \mathrm{bb} / \mathrm{ib})_{14}\right]$ complexes with $0 \leq \mathrm{x} \leq 1$; Relative contents of $\mathrm{Ln}$ and $\mathrm{Ln}$ ' for $\left[\mathrm{Tb}_{6 \mathrm{x}} \mathrm{Eu}_{6-6 \mathrm{x}}(3-\mathrm{cb} / \mathrm{bb} / \mathrm{ib})_{14}\right]$ complexes with $0 \leq \mathrm{x} \leq 1$; Projection view of the $\left[\mathrm{Dy}_{6}(3-\mathrm{cb})_{14}\right]$; Simplified projection view of the [Dy6 $\left.(3-\mathrm{cb})_{14}\right]$; Simplified projection view of a trinuclear triangle; Simplified projection view of the linkage of the two triangles; Coordination polyhedra of the three crystallographically independent $\mathrm{Dy}^{3+}$ ions in [Dy6 $\left.(3-c b)_{14}\right]$; UV-vis absorption spectra of $\left[\mathrm{Gd}_{6}(3-\mathrm{cb})_{14}\right],\left[\mathrm{Gd}_{6}(3-b b)_{14}\right]$ and $\left[\mathrm{Gd}_{6}(3-\mathrm{ib})_{14}\right]$ recorded at room-temperature; Emission spectra of $\left[\mathrm{Gd}_{6}(3-\mathrm{cb})_{14}\right], \quad\left[\mathrm{Gd}_{6}(3-\mathrm{bb})_{14}\right]$ and $\left[\mathrm{Gd}_{6}(3-\mathrm{ib})_{14}\right]$ recorded at $77 \mathrm{~K}$; Solid state emission spectra of $\left[\mathrm{Y}_{6 x} \mathrm{~Tb}_{6-6 x}(3-\mathrm{cb})_{14}\right]$, $\left[\mathrm{Y}_{6 x} \mathrm{~Tb}_{6-6 x}(3-\mathrm{bb})_{14}\right]$ and $\left[\mathrm{Y}_{6 x} \mathrm{~Tb}_{6-6 x}(3-\mathrm{ib})_{14}\right]$ vs $x$ under $294 \mathrm{~nm}, 308 \mathrm{~nm}$ or $328 \mathrm{~nm}$ excitation wavelength, respectively; $\mathrm{F}$ values versus $x$ for $\left[\mathrm{Tb}_{6 x} \mathrm{Eu}_{6-6 x}(3-\mathrm{cb})_{14}\right],\left[\mathrm{Tb}_{6 x} \mathrm{Eu}_{6-6 x}(3-b b)_{14}\right]$ and $\left[\mathrm{Tb}_{6 x} \mathrm{Eu}_{6-6 x}(3-\mathrm{ib})_{14}\right]$ with $0 \leq x \leq 1$; Plots presenting the thermometric parameter $v s$ temperature, $S_{a}$ values at variable temperature $(80-300 \mathrm{~K})$ and $S_{r}$ values at variable temperature $(80-300 \mathrm{~K})$ of $\left[\mathrm{Tb}_{4} \mathrm{Eu}_{2}(3-\mathrm{cb})_{14}\right]$; Plots presenting the thermometric parameter vs temperature, $S_{a}$ values at variable temperature $(80-300 \mathrm{~K})$ and $S_{r}$ values at variable temperature (80 - $300 \mathrm{~K})$ of $\left[\mathrm{Tb}_{4} \mathrm{Eu}_{2}(3-\mathrm{bb})_{14}\right]$; Plots presenting the thermometric parameter vs temperature, $S_{a}$ values at variable temperature $(80-300 \mathrm{~K})$ and $S_{r}$ values at variable temperature $(80-300 \mathrm{~K})$ of $\left[\mathrm{Tb}_{4} \mathrm{Eu}_{2}(3-\mathrm{ib})_{14}\right]$; Colorimetric coordinates of hexane solutions of $\left[\mathrm{Eu}_{3} \mathrm{~Tb}_{3}(3-\mathrm{cb})_{14}\right]$ vs concentration $\left(\mathrm{C}_{0}\right.$ to $\left.\mathrm{C}_{0} / 5\right)$; Emission spectra vs temperature of a $\left[\mathrm{Tb}_{4} \mathrm{Eu}_{2}(3-\mathrm{ib})_{14}\right]$ solution in heptane $\left(\mathrm{C}_{0}=2.10^{-3} \mathrm{~mol} \cdot \mathrm{L}^{-1}\right)$ between $200 \mathrm{~K}$ and $343 \mathrm{~K}$; Plots 
presenting the thermometric parameter vs temperature, $S_{a}$ values at variable temperature $(80-300 \mathrm{~K})$ and $S_{r}$ values at variable temperature $(200-340 \mathrm{~K})$ of $\left[\mathrm{Tb}_{4} \mathrm{Eu}_{2}(3-\mathrm{ib})_{14}\right]$ in heptane solution. 


\section{REFERENCES}

1. Bünzli, J. C. G., Rising stars in science and technology : Luminescent lanthanide materials. Eur. J. Inorg. Chem. 2017, 5058-5063.

2. Binnemans, K., Lanthanide based luminescent hybrid materials. Chem. Rev. 2009, 109, 42834374.

3. Yi, X.; Shang, J.; Pan, L.; Tan, H.; Chen, B.; Liu, G.; Li, R.-W.; Huang, G.; Bernot, K.; Guillou, O., Reversible luminescence modulation upon electric field on a full solid-state device based on lanthanide dimer. ACS Applied Materials \& Interfaces 2016, 8, 15551-15556.

4. Cui, Y.; Zhang, J.; He, H.; Qian, G., Photonic functional metal-organic frameworks. Chem. Soc. Rev. 2018, 47, 5740-5785.

5. Cui, Y.; Li, B.; He, H.; Zhou, W.; Chen, B.; Qian, G., Metal-organic frameworks as platforms for functionnal materials. Accounts Chem. Res. 2016, 49, 483-493.

6. Li, X.-Y.; Shi, W.-J.; Wang, X.-Q.; Ma, L.-N.; Hou, L.; Wang, Y.-Y., Luminescence modulation, white light emission and energy transfer in a family of lanthanide Metal-Organic Frameworks based on a planar $\pi$-conjugated ligand. Cryst. Growth Des. 2017, 17, 4217-4224.

7. Eliseeva, S. V.; Bünzli, J. C. G., Lanthanide luminescence for functionnal materials and biosciences. Chem. Soc. Rev. 2010, 39, 189-227.

8. Bünzli, J.-C. G., Lanthanide luminescence for biomedical analyses and imaging. Chem. Rev. 2010, 111, 2729-2755.

9. Guillou, O.; Daiguebonne, C.; Calvez, G.; Bernot, K., A long journey in lanthanide chemistry : from fundamental crystallogenesis studies to commercial anti-counterfeiting taggants. Accounts Chem. Res. 2016, 49, 844-856.

10. Wang, Y.-M.; Tian, X.-T.; Zhang, H.; Yang, Z.-R.; Yin, X.-B., Anticounterfeiting quick response code with emission color of invisible Metal-Organic Frameworks as encoding information. ACS Appl. Mater. Interfaces 2018, 10, 22445-22452.

11. Andres, J.; Hersch, R. D.; Moser, J. E.; Chauvin, A. S., A new counterfeiting feature relying on invisible luminescent full color images printed with lanthanide-based Inks. Adv. Func. Mater. 2014, 24, 5029-5036.

12. Panyarat, K.; Thammakan, S.; Ngamjarurojana, A.; Rujiwatra, A., Ratiometric luminescence behavior of lanthanide-mixed benzenedicarboxylate frameworks. Mater. Lett. 2018, 213, 166-169.

13. Errulat, D.; Marin, R.; Gálico, D. A.; Harriman, K. L. M.; Pialat, A.; Gabidullin, B.; likawa, F.; Couto, O. D. D.; Moilanen, J. O.; Hemmer, E.; Sigoli, F. A.; Murugesu, M., A Luminescent Thermometer Exhibiting Slow Relaxation of the Magnetization: Toward Self-Monitored Building Blocks for Next-Generation Optomagnetic Devices. ACS Central Science 2019, 10.1021/acscentsci.9b00288.

14. Brunet, G.; Marin, R.; Monks, M.-J.; Resch-Genger, U.; Galico, D. A.; Sigoli, F. A.; Suturina, E. A.; Hemmer, E.; Murugesu, M., Exploring the dual functionality of an ytterbium complex for molecular optical thermometry and slow magnetic relaxation. Chem. Sci. 2019, DOI: 10.1039/C9SC00343F.

15. Rao, X.; Song, T.; Gao, J.; Cui, Y.; Yang, Y.; Wu, C.; Chen, B.; Qian, G., A highly sensitive mixed lanthanide metal organic framework self calibrated luminescent thermometer. J. Am. Chem. Soc. 2013, 135, 15559-15564.

16. Cui, Y.; Zou, W.; Song, R.; Yu, J.; Zhang, W.; Yang, Y.; Qian, G., A ratiometric and colorimetric luminescent thermometer over a wide temperature range based on a lanthanide coordination polymer. Chem. Comm. 2014, 50, 719-721.

17. Ren, M.; Brites, D. S. C.; Bao, S.-S.; Ferreira, R. A. S.; Zheng, L.-M.; Carlos, L. D., A cryogenic luminescent ratiometric thermometer based on lanthanide phosphonate dimer. J. Mater. Chem. $C$ 2015, 3, 8480-8484.

18. Badiane, I.; Freslon, S.; Suffren, Y.; Daiguebonne, C.; Calvez, G.; Bernot, K.; Camara, M.; Guillou, O., High britness and easy color modulation in lanthanide-based coordination polymers with 
5-methoxyisophthalate as ligand: Toward emission colors additive strategy. Cryst. Growth Des. 2017, $17,1224-1234$.

19. Fan, X.; Freslon, S.; Daiguebonne, C.; Le Polles, L.; Calvez, G.; Bernot, K.; Guillou, O., A family of lanthanide based coordination polymers with boronic acid as ligand. Inorg. Chem. 2015, 54, 55345546.

20. Freslon, S.; Luo, Y.; Calvez, G.; Daiguebonne, C.; Guillou, O.; Bernot, K.; Michel, V.; Fan, X., Influence of photo-induced electron transfer on lanthanide-based coordination polymers luminescence : A comparison between two pseudo-isoreticular molecular networks. Inorg. Chem. 2014, 53, 1217-1228.

21. Cadiau, A.; Brites, D. S. C.; Costa, P. M. F. J.; Ferreira, R. A. S.; Rocha, J.; Carlos, L. D., Ratiometric nanothermometer based on an emissive $\mathrm{Ln}^{3+}$ organic framework. ACS Nano 2013, 7, 7213-7218.

22. Cui, Y.; Xu, H.; Yue, Y.; Guo, Z.; Yu, J.; Chen, Z.; Gao, J.; Yang, Y.; Qian, G.; Chen, B., A Luminescent mixed-lanthanide Metal-Organic Framework thermometer. J. Am. Chem. Soc. 2012, 134, 3979-3982.

23. Fan, X.; Freslon, S.; Daiguebonne, C.; Calvez, G.; Le Polles, L.; Bernot, K.; Guillou, O., Heteronuclear lanthanide-based coordination polymers exhibiting tunable multiple emission spectra. J. Mater. Chem. C 2014, 5510-5525.

24. Luo, Y.; Zheng, Y.; Calvez, G.; Freslon, S.; Bernot, K.; Daiguebonne, C.; Roisnel, T.; Guillou, O., Synthesis, crystal structure and luminescent properties of new lanthanide-containing coordination polymers Involving 4,4'-oxy-bis-benzoate as Ligand. Cryst. Eng. Comm. 2013, 15, 706-720.

25. Zhou, X.; Wang, H.; Jiang, S.; Xiang, G.; Tang, X.; Luo, X.; Li, L.; Zhou, X., Multifunctional luminescent material $\mathrm{Eu}(\mathrm{III})$ and $\mathrm{Tb}$ (III) complexes with pyridine-3,5-dicarboxylic acid linker; Crystal structures, tunable emission, Energy transfer and temperature sensing. Inorg. Chem. 2019, 58, 37803788.

26. Zhao, D.; Yue, D.; Jiang, K.; Zhang, L.; Li, C.; Qian, G., Isostructural Tb ${ }^{3+} / \mathrm{Eu}^{3+}$ co-doped MetalOragnic Framework based on pyridine-containing dicarboxylate ligands for ratiometric luminescence temperature sensing. Inorg. Chem. 2019, 58, 2637-2644.

27. Zheng, Z., Ligand-controlled self-assembly of polynuclear lanthanide-oxo/hydroxo complexes: from synthetic serendipity to rational supramolecular design. Chem. Comm. 2001, 10.1039/b107971a, 2521-2529.

28. Wang, R.; Selby, H. D.; Liu, H.; Carducci, M. D.; Jin, T.; Zheng, Z.; Anthis, J. W.; Staples, R. J., Halide-templated assembly of polynuclear lanthanide-hydroxo complexes. Inorg. Chem. 2002, 41, 278-286.

29. Guillerm, V.; Weselinski, L.; Belmabkhout, Y.; Cairns, A. J.; D'Elia, V.; Wojtas, L.; Adil, K.; Eddaoudi, M., Discovery and introduction of a $(3,18)$-connected net as an ideal blueprint for the design of metal-organic frameworks. Nat. Chem. 2014, 6, 673-680.

30. Luebke, R.; Belmabkhout, Y.; Weselinski, L.; Cairns, A. J.; Alkordi, M.; Norton, G.; Wotjas, L.; Adil, K.; Eddaoudi, M., Versatile rare earth hexanuclear clusters for the design and synthesis of highly connected ftw-MOFs. Chem. Sci. 2015, 6, 4095-4102.

31. Xue, D.-X.; Belmabkhout, Y.; Shekhah, O.; Jiang, H.; Adil, K.; Cairns, A. J.; Eddaoudi, M., Tunable rare earth fcu-MOF platform : Access to adsorption kinetics driven gas/vapor separations via pore siez contraction. J. Am. Chem. Soc. 2015, 137, 5034-5040.

32. Calvez, G.; Le Natur, F.; Daiguebonne, C.; Bernot, K.; Suffren, Y.; Guillou, O., Lanthanide-based hexanuclear complexes and their use as molecular precursors. Coord. Chem. Rev. 2017, 340, 134-153.

33. Alezi, D.; Peedikakkal, A. M. P.; Weselinski, L.; Guillerm, V.; Belmabkhout, Y.; Cairns, A. J.; Chen, Z.; Wojtas, L.; Eddaoudi, M., Quest for highly connected metal-organic framework platforms: rara earth polynuclear clusters versatility meets net topology needs. J. Am. Chem. Soc. 2015, 137, 5421-5430.

34. Zheng, Z., Cluster compounds of rare-earth elements. In Hanbook on the Physics and Chemistry of Rare Earths, Gschneidner, K. A.; Bünzli, J. C. G.; Pecharsky, V. K., Eds. Elsevier: 2010; Vol. 40, p 109-239. 
35. Grebenyuk, D.; Martynova, I.; Tsymbarenko, D., Self-assembly of hexanuclear lanthanide carboxylate clusters of three architectures. Eur. J. Inorg. Chem. 2019, 3103-311.

36. Mahé, N.; Guillou, O.; Daiguebonne, C.; Gérault, Y.; Caneschi, A.; Sangregorio, C.; ChaneChing, J. Y.; Car, P. E.; Roisnel, T., Polynuclear lanthanide hydroxo complexes : new chemical precursors for coordination polymers. Inorg. Chem. 2005, 44, 7743-7750.

37. Calvez, G.; Guillou, O.; Daiguebonne, C.; Car, P.-E.; Guillerm, V.; Gérault, Y.; Dret, F. L.; Mahé, N., Octaedral hexanuclear complexes involving light lanthanide lons. Inorg. Chim. Acta 2008, 361, 2349-2356.

38. Giester, G.; Unfried, P.; Zak, Z., Syntheses and crystal structures of some new rare earth basic nitrates II : $\left[\mathrm{Ln}_{6} \mathrm{O}(\mathrm{OH})_{8}\left(\mathrm{H}_{2} \mathrm{O}\right)_{12}\left(\mathrm{NO}_{3}\right)_{6}\right]\left(\mathrm{NO}_{3}\right)_{2} \cdot \mathrm{xH}_{2} \mathrm{O}, \mathrm{Ln}=\mathrm{Sm}, \mathrm{Dy}, \mathrm{Er} ; \mathrm{x}(\mathrm{Sm})=6, \mathrm{x}(\mathrm{Dy})=5, \mathrm{x}(\mathrm{Er})=4$. J. Alloys Compd. 1997, 257, 175-181.

39. Zak, Z.; Unfried, P.; Giester, G., The structures of some rare earth basic nitrates $\left[\operatorname{Ln}_{6}\left(\mu_{6}-O\right)\left(\mu_{3}-\right.\right.$ $\left.\mathrm{OH})_{8}\left(\mathrm{H}_{2} \mathrm{O}\right)_{12}\left(\mathrm{NO}_{3}\right)_{6}\right]\left(\mathrm{NO}_{3}\right)_{2} \cdot \mathrm{xH}_{2} \mathrm{O}, \mathrm{Ln}=\mathrm{Y}, \mathrm{Gd}, \mathrm{Yb} ; \mathrm{x}(\mathrm{Y}, \mathrm{Yb})=4, \mathrm{x}(\mathrm{Gd})=5$. A novel rare earth metal cluster of the $\mathrm{M}_{6} \mathrm{X}_{8}$ type with interstitial $\mathrm{O}$ atom. J. Alloys Compd. 1994, 205, 235-242.

40. Unfried, P., Isolation and characterization of four intermediates hydrates by isothermal dehydration of $\mathrm{Y}(\mathrm{OH})_{\times}\left(\mathrm{NO}_{3}\right)_{3-\mathrm{x} \cdot} \cdot \mathrm{yH}_{2} \mathrm{O}$. Thermochim. Acta 1997, 303, 119-127.

41. Giester, G.; Zak, Z.; Unfried, P., Syntheses and crystal structures of rare earth basic nitrates hydrates. J. Alloys Compd. 2009, 481, 116-128.

42. Calvez, G.; Daiguebonne, C.; Guillou, O.; Pott, T.; Méléard, P.; Le Dret, F., Lanthanide-based hexanuclear complexes usable as molecular precursor for new hybrid materials : state of the art. C. $R$. Chimie 2010, 13, 715-730.

43. Le Natur, F.; Calvez, G.; Guéguan, J. P.; Le Polles, L.; Trivelli, X.; Bernot, K.; Daiguebonne, C.; Neaime, C.; Costuas, K.; Grasset, F.; Guillou, O., Characterization and luminescence properties of lanthanide based polynuclear complexes nanoaggregates. Inorg. Chem. 2015, 54, 6043-6054.

44. Calvez, G.; Daiguebonne, C.; Guillou, O., Unprecedented lanthanide containing coordination polymers constructed from hexanuclear molecular building blocks: $\left\{\left[\mathrm{Ln}_{6} \mathrm{O}(\mathrm{OH})_{8}\right]\left(\mathrm{NO}_{3}\right)_{2}(\mathrm{bdc})(\mathrm{Hbdc})_{2}, 2 \mathrm{NO}_{3}, \mathrm{H}_{2} \mathrm{bdc}\right\}_{\mathrm{n}}$. Inorg. Chem. 2011, 50, 2851-2858.

45. Yao, H.; Calvez, G.; Daiguebonne, C.; Bernot, K.; Suffren, Y.; Puget, M.; Lescop, C.; Guillou, O., Hexalanthanide complexes as molecular precursors: synthesis, crystal structure and luminescent and magnetic properties. Inorg. Chem. 2017, 56, 14632-14642.

46. Abdallah, A.; Freslon, S.; Fan, X.; Rojo, A.; Daiguebonne, C.; Suffren, Y.; Bernot, K.; Calvez, G.; Roisnel, T.; Guillou, O., Lanthanide based coordination polymers with 1,4 carboxyphenylboronic ligand: multi emissive compounds for multi sensitive luminescent thermometric probes. Inorg. Chem. 2019, 58, 462-475.

47. Le Natur, F.; Calvez, G.; Daiguebonne, C.; Guillou, O.; Bernot, K.; Ledoux, J.; Le Polles, L.; Roiland, C., Coordination polymers based on hexanuclear rare earth complexes : Toward independant luminescence brightness and color emission. Inorg. Chem. 2013, 52, 6720-6730.

48. Altomare, A.; Burla, M. C.; Camalli, M.; Carrozzini, B.; Cascarano, G.; Giacovazzo, C.; Guagliardi, A.; Moliterni, A. G. G.; Polidori, G.; Rizzi, A. C., EXPO: a program for full powder pattern decomposition and crystal structure solution. J. Appl. Crystallogr. 1999, 32, 339-340.

49. Sheldrick, G. M.; Schneider, T. R., SHELXL : High-Resolution Refinement. Macromol. Crystallogr. B 1997, 319-343.

50. Farrugia, L. J., WinGX suite for smallmolecule single-crystal crystallography. J. Appl. Crystallogr. 1999, 32, 837-838.

51. Sluis, P.; Spek, A. L., BYPASS: an Effective method for the refinement of crystal structures containing disordered solvent regions. Acta Crystallogr. A 1990, A46, 194-201.

52. Chauvin, A. S.; Gumy, F.; Imbert, D.; Bünzli, J. C. G., Europium and terbium tris(dipicolinate) as secondary standards for quantum yield determination. Spectrosc Lett 2004, 37, 512-532.

53. Sendor, D.; Hilder, M.; Juestel, T.; Junk, P. C.; Kynast, U., One dimensional energy transfer in lanthanoid picolinates. Correlation of structure and spectroscopy. New J. Chem. 2003, 27, 1070-1077.

54. CIE, International Commission on Illumination - Technical report. CIE: 1995; Vol. 13-3, p 16. 
55. Wyszecki, G., Colorimetry. In Handbook of Optics, Driscoll, W. G.; Vaughan, W., Eds. Mac Graw-Hill Book Company: New-York, 1978, p 1-15.

56. Guillou, O.; Daiguebonne, C.; Calvez, G.; Le Dret, F.; Car, P. E., Structuring effect of $\left[\mathrm{Ln}_{6} \mathrm{O}(\mathrm{OH})_{8}\left(\mathrm{NO}_{3}\right)_{6}\left(\mathrm{H}_{2} \mathrm{O}\right)_{12}\right]^{2+}$ entities. J. Alloys Compd. 2008, 451, 329-333.

57. Calvez, G.; Bernot, K.; Guillou, O.; Daiguebonne, C.; Caneschi, A.; Mahé, N., Sterically-induced synthesis of 3d-4f one-dimensional compounds: a new route towards 3d-4f Single Chain Magnets. Inorg. Chim. Acta 2008, 361, 3997-4003.

58. Casanova, D.; Llunell, M.; Alemany, P.; Alvarez, S., The rich stereochemistry of eight-vertex polyhedra: A continuous shape measures study. Chem. - Eur. J. 2005, 11, 1479-1494.

59. Alvarez, S.; Alemany, P.; Casanova, D.; Cirera, J.; Llunell, M.; Avnir, D., Shape maps and polyhedral interconversion paths in transition metal chemistry. Coord. Chem. Rev. 2005, 249, 16931708.

60. Fourmigué, M., Halogen bonding: Recent advances. Current Opin. Solid St. M. 2009, 36-45.

61. Bünzli, J. C. G.; Eliseeva, S. V., Basics of lanthanide photophysics. In Lanthanide Luminescence, Hänninen, P.; Härmä, H., Eds. Springer Berlin Heidelberg: 2010; Vol. 7, p 1-45.

62. Piguet, C.; Bünzli, J. C. G.; Bernardinelli, G.; Hopfgatner, G.; Williams, A. F., Self-assembly and photophysical properties of lanthanide dinuclear triple-helical complexes. J. Am. Chem. Soc. 1993, $115,8197-8206$.

63. Dexter, D. L., A theory of sensitized luminescence in solids. J. Chem. Phys. 1953, 21, 836-850.

64. Förster, T., Comparative effects of radiation. John Wiley \& Sons: New-York, 1960.

65. Weissman, S. I., Intramolecular energy transfer - The fluorescence of complexes of europium. J. Chem Phys 1942, 10, 214-217.

66. Carnall, W. T.; Fields, P. R.; Rajnak, K., Energy levels in the trivalent lanthanide ions. III. Tb ${ }^{3+}$. J. Chem. Phys. 1968, 49, 4447-4450.

67. Carnall, W. T.; Fields, P. R.; Rajnak, K., Spectral intensities of the trivalent lanthanides and actinides in solution. II. $\mathrm{Pm}^{3+}, \mathrm{Sm}^{3+}, \mathrm{Eu}^{3+}, \mathrm{Gd}^{3+}, \mathrm{Tb}^{3+}, \mathrm{Dy}^{3+}$ and $\mathrm{Ho}^{3+}$. J. Chem. Phys. 1968, 49, 44124423.

68. Carnall, W. T.; Fields, P. R.; Rajnak, K., Electronic energy levels of the trivalent lanthanide ions. IV. Eu ${ }^{3+}$. J. Chem. Phys. 1968, 49, 4450-4455.

69. Haquin, V.; Etienne, M.; Daiguebonne, C.; Freslon, S.; Calvez, G.; Bernot, K.; Le Polles, L.; Ashbrook, S. E.; Mitchell, M. R.; Bünzli, J. C. G.; Guillou, O., Color and brightness tuning in heteronuclear lanthanide teraphthalate coordination polymers. Eur. J. Inorg. Chem. 2013, 3464-3476.

70. Latva, M.; Takalo, H.; Mukkala, V.-M.; Matachescu, C.; Rodriguez-Ubis, J. C.; Kankare, J., Correlation between the lowest triplet state energy level of the ligand and lanthanide luminescence quantum yields. J. Lumin. 1997, 75, 149-169.

71. D'Aléo, A.; Pointillart, F.; Ouahab, L.; Andraud, C.; Maury, O., Charge transfer excited states sensitization of lanthanide emitting from the visible to near infra red. Coord. Chem. Rev. 2012, 256, 1604-1620.

72. Bhaumik, M. L.; Nugent, L. J., Time-Resolved Spectroscopy of Europium Chelates. J. Chem. Phys. 1965, 43, 1680-1687.

73. Dawson, W. R.; Kropp, J. L.; Windsor, M. W., Internal-Energy-Transfer Efficiencies in Eu ${ }^{3+}$ and $\mathrm{Tb}^{3+}$ Chelates Using Excitation to Selected Ion Levels. J. Chem. Phys. 1966, 45, 2410-2418.

74. Beeby, A.; Bushby, L. M.; Maffeo, D.; William, J. A. G., The efficient intramolecular sensitisation of terbium(III) and europium(III) by benzophenone-containing ligands. Journal of the Chemical Society Perkin Transactions 2 2000, 1281-1283.

75. Prodi, L.; Maestri, M.; Ziessel, R.; Balzani, V., Luminescent $\mathrm{Eu}^{3+}, \mathrm{Tb}^{3+}$ and $\mathrm{Gd}^{3+}$ complexes of a branched triazacyclononane ligand containing three 2,2'bipyridine units. Inorg. Chem. 1991, 30, 3798-3802.

76. Galaup, C.; Couchet, J.-M.; Bedel, S.; Tisnès, P.; Picard, C., Direct access to terpyridinecontaining polyazamacrocycles as photosensitizing ligands for $\mathrm{Eu}(\mathrm{III})$ luminescence in aqueous media. J. Org. Chem. 2005, 70, 2274-2284. 
77. Ward, M. D., Transition metal sensitized near infrared luminescence from lanthanide in d-f heteronuclear arrays. Coord. Chem. Rev. 2007, 251, 1663-1677.

78. Clark, D. T.; Murrell, J. N.; Tedder, J. M., The magnitudes and signs of the inductive and mesomeric effects of the halogens. Journal of the Chemical Society 1963, 1250-1253.

79. Steemers, F. J.; Verboom, W.; Reinhoudt, D. N.; Van der Tol, E. B.; Verhoeven, J. W., New sensitizer-modified calix[4]arenes enabling Near-UV Excitation of complexed luminescent lanthanide ions. J. Am. Chem. Soc. 1995, 117, 9408-9414.

80. Rodrigues, M. O.; Dutra, J. D. L.; Nunes, L. A. O.; de Sa, G. F.; de Azevedo, W. M.; Silva, P.; Paz, F. A. A.; Freire, R. O.; Junior, S. A., $\mathrm{Tb}^{3+}->\mathrm{Eu}^{3+}$ energy transfer in mixed lanthanide organic frameworks. J. Phys. Chem. C 2012, 116, 19951-19957.

81. Selvin, P. R.; Rana, T. M.; Hearst, J. E., Luminescence resonance energy transfer. J. Am. Chem. Soc. 1994, 116, 6029-6030.

82. Rocha, J.; Brites, D. S. C.; Carlos, L. D., Lanthanide organic framework luminescent thermometers. Chem. - Eur. J. 2016, 22, 14782-14795.

83. Cadiau, A.; Brites, D. S. C.; Costa, P. M. F. J.; Ferreira, R. A. S.; Rocha, J.; Carlos, L. D., Ratiometric nanomether based on an emissive $\operatorname{Ln}^{3+}$-organic framework. ACS Nano 2013, 7, $7213-$ 7218.

84. Brites, D. S. C.; Lima, P. P.; Silva, N. J. O.; Millan, A.; Amaral, V. S.; Palacio, F.; Carlos, L. D., Lanthanide-based luminescent molecular thermometers. New J. Chem. 2011, 35, 1177-1183.

85. Cui, Y.; Sog, R.; Yu, J.; liu, M.; Wang, Z.; Wu, C.; Yang, Y.; Wang, Z.; Chen, B.; Qian, G., Dual emitting MOF-Dye composite for ratiometric temperature sensing. Adv. Mater. 2015, 27, 1420-1425.

86. Chuasaard, T.; Ngamjarurojana, A.; Surinwong, S.; Konno, T.; Bureekaew, S.; Rujiwatra, A., Lanthanide coordination polymers of mixed phthalate/adipate for ratiometric temperature sensing in the upper-intermediate temperature range. Inorg. Chem. 2018, 57, 2620-2630.

87. Brites, D. S. C.; Millan, A.; Carlos, L. D., Lanthanides in Luminescent Thermometry. In Handbook on the Physics and Chemistry of Rare Earths, Gschneidner, K. A.; Bünzli, J. C. G.; Pecharsky, V. K., Eds. Elsevier: 2016; Vol. 49, p 339-427. 
TABLE OF CONTENT

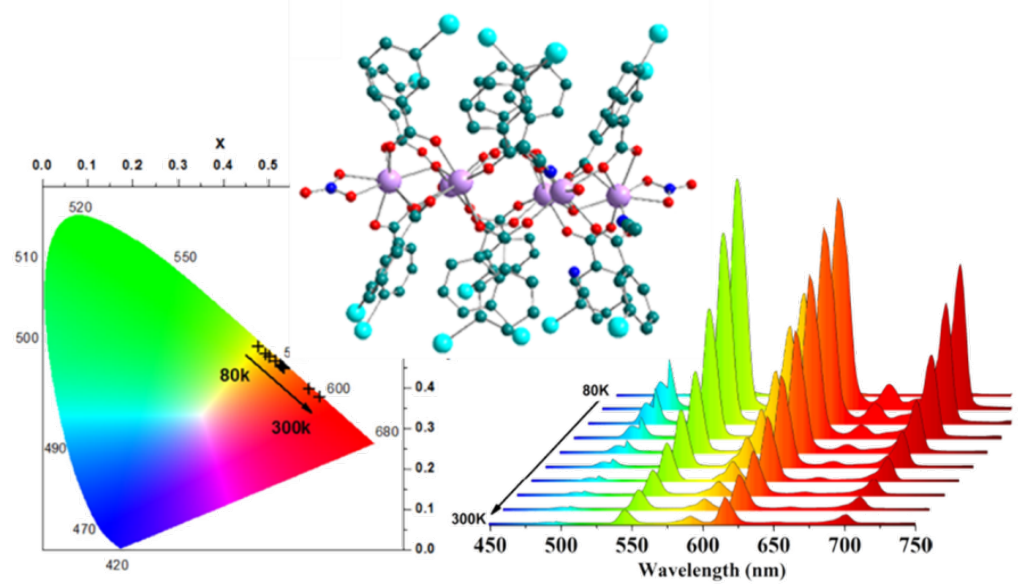

Hetero-hexa-lanthanide complexes with m-halogeno-benzoate have been synthesized and structurally described. They present interesting thermo-dependent luminescence. 